\title{
LINGUISTIC EVIDENCE FOR THE INTRODUCTION OF IRONWORKING INTO BANTU-SPEAKING AFRICA
}

\author{
JAN VANSINA \\ UNIVERSITY OF WISCONSIN-MADISON
}

Did Africans once independently invent the smelting of metals or did they obtain this technology from Europe or the Middle East? This continues to be an unresolved and hotly disputed issue, mainly because the dates for the earliest appearance of smelting in Africa south of the Sahara remain inconclusive. All the earliest sites in Western and West-Central Africa from Walalde in Senegal to the Tigidit cliffs and Termit in Niger, the firki plains south of lake Chad, Taruga, and perhaps Nsukka in Nigeria, Ghwa Kiva (Nigeria), and Doulo (Cameroon) in the Mandara mountains, Gbabiri (Ndio district) in the Central African Republic, and a few sites in Rwanda, Burundi, and Buhaya cannot be dated more closely than between 840 and 420 BCE. Greater precision is impossible because the $\mathrm{C} 14$ curve runs flat during these four centuries, hence all these sites yield the same date. (Alpern, Killick, Mc Eachern, Holl, Jézégou/Clist, Kanimba Misago). If the earliest "real" dates fell before $800 \mathrm{BCE}$, they would support independent invention, while later dates strengthen the case for borrowing. Still, this information does tell us that ironworking was adopted in the northern parts of West and West -Central Africa and in the region of the Great Lakes within the span of a mere four centuries.

The emergence of ironworking must have left linguistic traces in the relevant terminology irrespective of whether it spread by borrowing or by independent invention-hence historical linguistics can contribute to this debate. That approach is best tested by an examination of the relevant vocabulary in Bantu languages because the historical study of those languages is further advanced than that of any other language family in
\end{abstract}


Africa (Nurse/Phillipson). Moreover Bantu-speakers occupy a large portion of the continent.

Thirty years ago François Nsuka and Pierre de Maret (de Maret/Nsuka; Nsuka/de Maret) established that no single word relating to metallurgy in any Bantu language could confidently be attributed to Proto-Bantu (hereafter $\mathrm{PB}$ ) and hence they argued that PB-speakers did not know how to work iron; that skill was acquired only after PB had begun to split and its daughter languages were spreading over the sub-continent that they now occupy. Nevertheless, they continued tacitly to assume that ironworking diffused only once and from a single cradle throughout most of the Bantuspeaking area and all subsequent scholars with the exception of KleinArendt have accepted this stance.

In an essay originally written in 1973, but updated later and published only recently, Christopher Ehret (2003) reached the same conclusion, and went on to claim that within the Bantu-speaking world ironworking first appeared in the Great Lakes region and diffused from there all over the subcontinent. He further argued that the ironworking vocabulary in the cradle region itself was probably derived from Central and/or East Sudanic languages and hence that ironworking probably diffused from the Nile valley. This essay is seriously flawed, mainly because his database is deficient, especially for languages other than Eastern Bantu, and his assertions are often not supported by the data cited.

Meanwhile, in 2004 Klein-Arendt published a massive set of words about iron working in "savanna Bantu," i.e., the Bantu languages of eastern, southern, and east-central Africa as part of an ongoing study to document all the Bantu "migrations" and "cultural" diffusions that have succeeded each other across this area from the onset until the very recent past. With regard to the advent of ironworking, he cautions that the huge lacunae that exist in the documentation of adjacent non-Bantu languages prevent us from making definitive assertions, but still concludes that there were very likely one or several initial introductions of ironworking from West Africa, as well as one or several more from Northeast Africa (KleinArendt 257). Still it seems to me that the addition of further data from other than narrow Bantu languages now allows one to reach a few clear conclusions about this question. They warrant the following contribution.

Excluding words that refer to the products of metalworking, the vocabulary relating to iron-smelting and forging consists today of between 30 and 40 different items, most of which were coined long after the initial acquisition of ironworking and document technological changes during 
the millennia that followed the initial introduction of ironworking. In order to find those among them that do relate to the initial appearance of metallurgy, we, like our predecessors, must rely on the geographic extent and geometric shape of the distribution of their reflexes. Firstly, reflexes of the most ancient words are likely to be widely distributed, yet all widely distributed words are not necessarily of great antiquity. Secondly, with rare exceptions, discontinuous geographic distributions indicate considerable antiquity, while most (not all!) continuous or "block" distributions are of more recent origin. Thirdly, the meanings of reflexes of old words have diverged further from the initial meaning of the ancestral item than is the case for reflexes of recent words, because more time has passed since their inception, although there are also exceptions to this rule. Fourthly, a knowledge of the etymology of a word and of its subsequent shifts of meaning often allow one to locate its origin and the direction of its diffusion. ${ }^{1}$

We start by examining words only glossed as "iron," a gloss that implies a generic meaning. Yet in fact such forms often refer to a specialized meaning and hence a single language can well have several words that may all be glossed as "iron" in the dictionary. For instance, Nyiha has umuthale "bloom-product of the first smelt;" imbulo "refined iron ready for forging;" ishijela "a piece of forged iron;" and ishuma "the metal iron, or "valuable property" (Busse; 88, 105-07 for all the forms, 144-59 for two of these). This example illustrates the importance of precise glosses. Furthermore, it follows from the existing imprecision of many glosses that the documented distribution areas for each of the rubrics "iron generic," "bloom," "refined iron ready for forging," "forged iron"and "pieces or objects in iron" are probably incomplete and also that distribution areas for different words glossed only as "iron" can be expected to overlap with each other. Still, in spite of the incomplete character of their distributions, an examination of the words involved yields a scenario that is far more likely to reflect the past than any alternative. This scenario underlies the order of the following presentation.

\section{III}

The first introduction of ironworking is indicated by the distributions of the following words "-bo\#lo\# "iron, bloom,"2 "-(j)o\#ndo "sledgeham-

\footnotetext{
${ }^{1}$ For the relevant methodologies see Klein-Arendt, 43-102. Reflexes are present-day attestations of an ancestral form.

${ }^{2}$ Where relevant in seven or more vowel languages \# distinguishes the vowel of the second degree from the vowel of the third degree: hence $e \#$ versus $e$ and o\# versus $O$. Starred forms represent the most probable ancestral form in Proto-Bantu or in another genetic grouping, while forms preceded by ${ }^{\circ}$ are either the postulated original form of a loanword or a summary of the set of variant forms of that loanword.
} 
mer," and "-túd- "to forge," with its derivation *-túdi "smith." These words are attested north and northwest of the Bantu-speaking area and are very widely distributed within it. Starting with "-bo\#lo\# "iron, bloom," we cite all the reflexes known to us because this word has not been recognized as relevant by Guthrie, de Maret/Nsuka, and KleinArendt, while the distribution given by Ehret is quite incomplete.

-bo\#lo\# (in Bantu 11/10 or 9/10) "iron" unless otherwise specified ${ }^{3}$ -Map 1

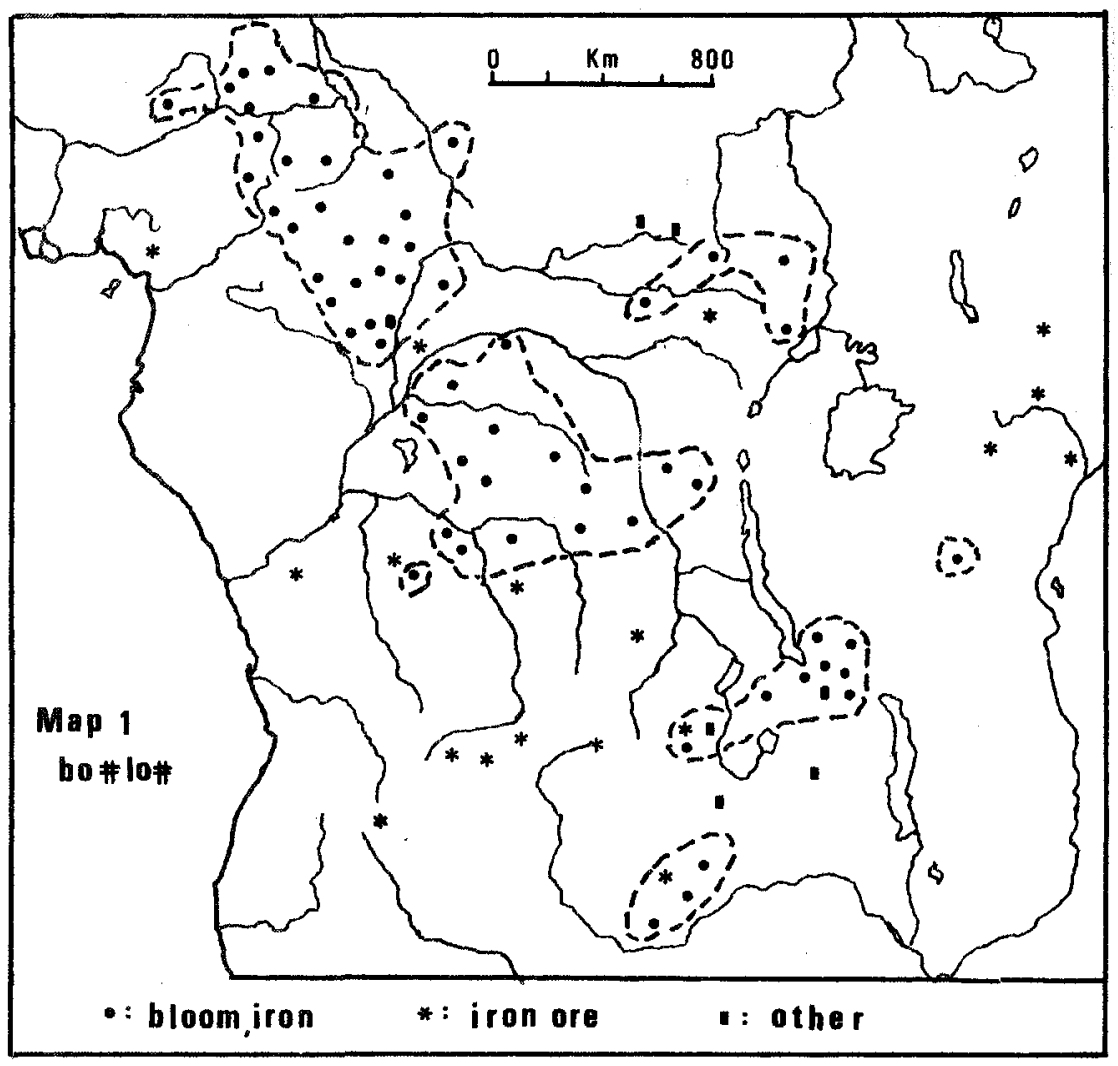

${ }^{3}$ Reference to the relevant lexicon as the source of a word in any particular language is not indicated in our wordlists, as this information can easily be found by consulting the bibliographies of Bastin, Hendrix, and Meier. or Klein-Arendt, 277-98. I cite only the source and page number for a reflex when it is culled from another source. 


\section{Western Non-Bantu}

\begin{tabular}{|c|c|}
\hline Mbula & $\begin{array}{l}\text { bolo }{ }^{4} \text { (Lukas and Gerhardt 77, 79; Meek } 1931 \text { 1:57, } \\
63-64 \text { ) }\end{array}$ \\
\hline Jarawa & $\begin{array}{l}\text { u-voal, (Johnston 721) Pin-vuol (Johnston 721), u-val } \\
\text { (Koelle 82) }\end{array}$ \\
\hline Lamang & $\begin{array}{l}-v o ̈ l \text { in } n d u v o ̈ l ~(n d u+v o ̈ l ?) \text { "hammer" (Wente Lukas } \\
87 / 5)\end{array}$ \\
\hline Daba & $\begin{array}{l}-v^{\wedge} l \text { in } n d u v^{\wedge} l\left(n d u+v^{\wedge} l\right) \text { "anvil" (Mouchet } \\
1966: 188)\end{array}$ \\
\hline Bata & $b^{\wedge}$ lo\# "smith"(Mouchet 1950:54) \\
\hline Mata (Fianga) & bo (Lukas 103) \\
\hline Laka (Lakka) & $m b o l($ Tessmann 75) \\
\hline Mbum (Mboum) & $\begin{array}{l}\text {-mbol, femvol, fembol (Hino Shun'ya 290; Hagege } \\
\text { 32; Périquet 6, Tessmann 65) }\end{array}$ \\
\hline Gbaya yaayuwee & bo\#i, bo\#yo\# (Noss 11) \\
\hline Gbaya kara & bo\#yo\# (Moñino 112) \\
\hline Gbaya biyanda & bo\#lo\# (Moñino 112) \\
\hline Gbaya booro & bo\#ro\# (Moñino 112) \\
\hline Gbeya & bo\#ro\# (Samarin) \\
\hline Manja & boyo (Gaud 346; Vergiat 106; Moñino 112) \\
\hline Manza & bo\#l\#o (Renouf -Stefanik 334) \\
\hline Gbaya, mbo\#domo & bo\#lo\# (Noss 11) \\
\hline Gbaya Dooka & $b o \# R \# o$ (Noss 11) \\
\hline Gbaya Lai & bo\#Ro\# (Noss 11) \\
\hline Gbaya Kunde & burro (Charreau 198) \\
\hline Bofi & bo\#dfo\# "bloom" (Bahuchet 108) \\
\hline Ngbaka RDC & bo\#lo\# (Maes) \\
\hline Ngbaka Mabo & gbo bolo "bloom" te bolo "to forge"(Calloc'h) \\
\hline Monzombo & bo\# "bloom"(Wambat 2: 206, 209) \\
\hline Barambu (Doruma) & boro (Tucker/Hackett 255) \\
\hline Barambu (Amiangba) & boro (Tucker/Hackett 255) \\
\hline Pambia & bolo "iron ore" \\
\hline Mayogo & buru boro "smith"; -boboro "to forge" (Meyer 10). \\
\hline Lendu (Ndru) & $\begin{array}{l}\text { mbo (Czekanowski 6/2:701, Johnston, II : 939) } \\
m b r o ́ ~(S t r u c k: 150)\end{array}$ \\
\hline
\end{tabular}

\footnotetext{
${ }^{4}$ Apart from Mbula and Jarawa, "iron" is not listed in any other accessible wordlists of Jarawan languages. One can, however, expect bo\#lo\# to occur also in nearby Bwazza (Bare) and Tambo which are closely related to Mbula, as well as Bile (Meek 1931, 1:57; (Maddieson/Williamson, 134-35). But given the Jarawa form cited, other Jarawan languages may also have the word, for even with the two attested occurrences it is not excluded that bo\#lo\# was Proto-Jarawan, nor that the word was first coined in ProtoJarawan, i.e., not far from the Early Iron Age Nok Culture.
} 
Beli

Kare (Bantu)

Basa Komo

Mbati

Pande

Yakinga

Kaka Kadei

bolo "iron" (Ehret 165)

gboro mala "iron ore"

\section{Possibly}

oshambule "iron" (Koelle 83 if-bul- is the root).

\section{Bantu: Ubangi-Sangha}

mboli

bolio (Ouzilleau)

bodian (Périquet 40)

poro (Périquet 470; Noss has yobú (Bera) and djobú (Mkako)

Possibly

Mpiemu jóó (Copet)

Bokabonga (Babole?) bojio (Périquet 52)

Lingala

mbolo 9 (Courboin 108) and mbôlo 3 "special knife of honor"(Cambier 36)

Loleku

bolo 11

\section{Northwest and West}

Kongo (Manyanga) - - bulu 5/6 "furnace" (Volavka190)

Mbala

-bulu 3/4 "needle for matting"

Possibly

Tanga (near Londo), - -bola "hammer" (Mansfeld 288)

Mbala

-buulu 5/6 "strip of iron"

\section{Cuvette and North central}

Mongo

-(b)o\#lo\# 11/10 (lo\#o\#lo\#, mbo\#lo\#) and all dialects "bloom"

Ndengese

-(b)o\#lo\# 11/10 "bloom"

Yela (Kela)

Tetela

-(b)o\#lo\# 11/10 or -(b)ulu (Johnston)

-wo\#lo\# 11/10 and dialects

Kusu

-(b) ulu 11/10 or -bolo (Czekanowski 6/2:618;

Johnston)

Sungu

-mbulu (Torday 220)

${ }^{5}$ Laman and other dictionaries mention -búlu 5/6 "pit," which seems to be derived from

"furnace" rather than the reverse. 
Kutu

Kela

Bushong

Wongo

Lele

South Kete

Binja North

Lega Pangi (Beya)

Luba Kat

Luba Kat

LubaKat

Fipa

Mambwe

Namwanga

Namwanga

Nyiha

Nyiha

Iwa

Bemba

Bisa

Lala

Lamba

Lamba

Tonga plateau

Tonga valley

Tonga-We

Ila

Ila

Ndembu

Lwena

Cokwe

Lucazi

Nyemba -lolo 11 (Frobenius 4:197) -bulu (Torday 220)

-bulu (Torday 220)

-bo\#l 11/10 "bloom"

-buri 11/10 (Johnston)

-bulu 11/10 (Johnston)

mburru " iron ingot" (Klein 3: 41, 170)

\section{Maniema and East Central}

-bulu 11/10 (Delhaise 211)

-bulu 12 "bloom" (Kita 90, 93)

-bulo 12/13 "petite pique"

um-bulo / im-bulo "pique pointe en fer"

-bulo (ku/ma) 15/6 "trident"

-lu-ulo 11, lu-olo 11/i-mbulo 10 "bloom"(Klein-

Arendt 380)

-lu-lo/i-mbulo 11/10 "bloom"(Klein-Arendt 380)

-lu-wulo/i-mbulo 11/10 “bloom'(Klein-Arendt 380)

$i$-mbulo 9 "iron ore" (Klein-Arendt 380)

i-mbulo 9 "refined iron" (Busse 107)

i-mbulo 9 "bloom"(Klein-Arendt 380)

-lu-wulo 11 "bloom" (Klein-Arendt 380)

-bulo 11/10 "bloom"

i-mbule 10 "ironore" (Klein-Arendt 349)

i-mbule 10 "ironore" (Klein-Arendt 349)

i-mbule 10 "ironore" (Klein-Arendt 349)

-lu-wulo 11 "bloom" (Klein-Arendt 380)

\section{Middle Zambezi and Moxico}

-bulo 11 and 14

-bulo 11 and 14

-bulo 11/10 (Reynolds 94)

-bulo 5 "large iron tool"

-mbulo 14, "large iron tip spear" 12, "small iron tip spear"

-bulu 3/4 "small metal" or "ankle ring" [loan because of initial $b$ ]

-ulu 12 "cylindrical hammer"

-ulu 12 "cylindrical hammer"

-vulo 12 "small hammer"

-vulo 12 "small hammer" 


\section{Northeast : Bantu and Oromo}

$\begin{array}{ll}\text { Langi } & \text { mbiro "iron ore" (Ehret 129-30) } \\ \text { Langi } & \text {-buula } 11 \text { (Johnston) "iron" } \\ \text { Pokomo } & \text { burisa "anvil" (Klein-Arendt 233) } \\ \text { Kikuyu } & \text {-bura } 3 / 4 \text { "bellows" (Klein-Arendt 233) } \\ \text { Tharaka } & \text {-bura } 3 / 4 \text { "bellows" (Klein-Arendt 233) } \\ \text { Oromo } & \text { burruusa "hammer" (Klein-Arendt 233) }\end{array}$

The great antiquity of the spread of ${ }^{\circ}-$ bo\#lo\# is vouchsafed by the extent and the discontinuous distribution of its reflexes. In addition to the reflexes we cite here, there also exists a set of ${ }^{\circ}$-bili words for "iron" in Adamawa that are possibly related to ${ }^{\circ}-b o \# l o \#$, although the difference in vowels remains unaccounted for. ${ }^{8}$ Hence we exclude these from the distribution of the reflexes. Should it in future be shown that they should be included, the distribution of ${ }^{\circ}-$ bo\#lo\# would be considerably extended on the Adamawa plateau.

The etymology of ${ }^{\circ}$-bo\#lo\# remains unknown and that prevents conclusive determination of its origin..$^{9}$ But the shape of its distribution, as well as the available archeological documentation-which points to a diffusion from northwest to southeast and not the reverse-as well as he probability that the form existed in proto-Gbaya point to an origin in the Nigerian plateau state not far from Nok. If so, the word, and presumably ironworking with it, then spread from its cradle lands both eastwards as far as Lake Albert and the vicinity of Rumbek west of the Nile, and southeastwards to the lands between the Sanga and Ubangi rivers, through the central rainforests and then further south and east through savannas as far south as the central Zambezi valley. It thus cut right across the middle of the Bantu -speaking areas. Later it diffused, with shifts of meaning, westwards into eastern Angola, and possibly also northeastwards from the Lakes Tanganyika-Malawi corridor as far as the Tana river valley. Its spread began some time after $840 \mathrm{BCE}$, reached the great lakes by $c a .450$

6Ehret, Establishment, 127, interprets Langi mbiro, "iron ore," as a skewed reflex of - bo\#lo\#, but this is not likely since he posits a PB form for the latter.

${ }^{7}$ The divergent vowels in ${ }^{\circ}$-bura make a derivation from ${ }^{\circ}$-bo\#lo\# rather unlikely. In addition, these words-and despite Klein-Arendt's opinion (233) -may just as well have spread from a Bantu language to Oromo rather than the reverse.

${ }^{8}$ These are Tera vi (Meek 1931, 2: 423); Hinna vi, (ibid., 429); Jen bi (ibid., 536); Munga bi (ibid., 536); Vere bil (Blakney 96); Hona te +billa, "smith" (Meek 1931, 2:411); Somrai biri (Lukas 83); Giziga bira (Pontié 231); Mambila birra, bila (Blakney 96); Longuda billa' "iron" (Meek 1931, 2:361, 367); Sukur dibil, dubul "iron money" (Wente-Lukas 91); and De Maret/Nsuka (1977:45)

'Despite a superficial resemblance, -bo\#lo\# "iron" is not related at all to bó\#lö\# 3/4 [bo\#-o\#lo\#] "strength" in the Mongo languages, Bushong, and the languages of lakes Mayi Ndombe and Tumba. Both the roots and their tones differ. 
BCE at the latest, and ended by the second century CE or so, since the earliest known iron age site in Zambia dates to about 100 CE (Robertson 152) and the word is not found anywhere in southern Angola or south of the Zambezi, even though ironworking itself spread from southern Zambia to southwestern Angola.

\section{IV}

Even more widespread are three words related to forging that had been ascribed to PB by all linguists before Nsuka. The first two of these are "túd- "to forge," and its derivative "-túdi 1/2 "smith." Their reflexes have been well documented (Guthrie 1:122 \# 73.65, and topogram 132, CS403, CS1861; de Maret/Nsuka 49-50, and Klein-Arendt 536-47). The forms are undoubtedly $\mathrm{PB}$ and occur everywhere in the Bantu-speaking areas except for a bloc of languages in southern and central Tanzania, Zulu and Xhosa. The words are also found beyond Bantu in some Bantoid and Ubangian languages. One reflex even stems from as far away as Ewe (de Maret $\mathbb{N}$ suka 51). ${ }^{10}$ We cite the non-Bantu reflexes known to us, and add a few neighboring Bantu ones.

Non Bantu *-túl- "to forge"-Map 2

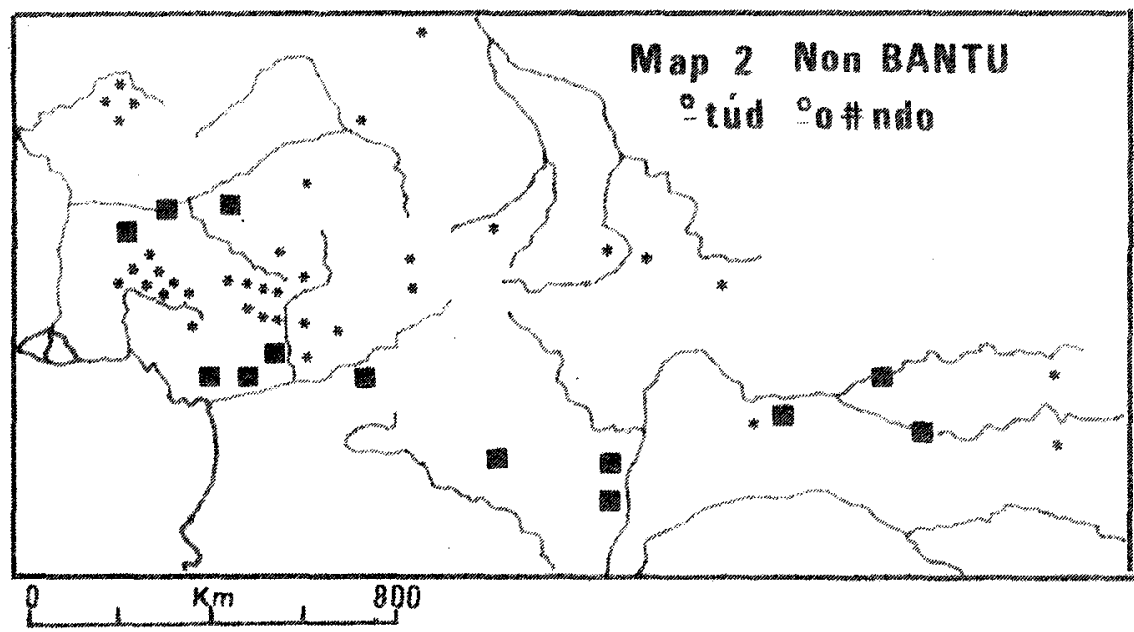

: - túd

: : $: 0$ ndo

${ }^{10}$ Crabb 56; Thomas 29; Nsuka, HA5. Gbaya dúi, dóé, dól "to forge," Munzombo Ju luba; Nsuka (Ewe). 


\section{Jos Plateau}

Kagoro

Kaje

Katab

Iregwe

Chawai

Proto-Plateau

Proto-Plateau

Kaje

Kagoro

Katab

Morwa

Jaba $a-t w u-u(\mathrm{sg}), a-t w u ́-b a ́(\mathrm{pl})$ "blacksmith"(Gerhardt 177, 299)

a-tshu "blacksmith" (Gerhardt 51)

$o$-fu "blacksmith" (Meek 2:82)

$n e$-cu (LL ${ }^{11}$-sg) Ÿ-ne-cú (HHH-pl) "blacksmith"

(Gerhardt 132, 137)

e-turi "blacksmith" (Meek 2:159)

Possibly

TUAT “to beat" (Gerhardt 227) $[t u+a t]$

TUAM "iron" (Gerhardt 227) [tu $+a m]$

tsoam "iron" (Meek 2:107)

chuam "iron" (Meek 2:99)

cham "iron" (Meek 2:83)

cham "iron" (Meek 2:118)

djom "iron" (Meek 2:124)

\section{Jarawan}

Mbula

Mbula

Jaku

Bankal

Jarawa

Proto Jukun-Mbembe

-túl Ÿng "to forge" (Gerhardt 80) -tula "to forge" 9 (Lukas/Gerhardt 77, 79, 84;

Gerhardt 80, 82, 910)

mintul "smith" (Meek 1:64)

-túlum "to forge" (Gerhardt 80)

$a-t u$ (pl) $a-t u ́$ "blacksmith" (Lukas/Willms)

*tán "iron money" (Kiyoshi Shimizu 2:289 and

Storch 341 suggested because of the relationship with Wide Bantu -tún "iron." This form must have been introduced separately and later than the ${ }^{\circ}-t u l$ forms in Jarawan.

\section{Ekoid-Mbe and Bankong (Abo 2) "to forge"}

Eight Ekoid languages of Ogoja have $-t \hat{u} i,-c \hat{u} i,-t \hat{u} l, t \hat{o} l,-t \ddot{Y} l$ and four others as $t^{\wedge} n$ or ten, "blacksmithing"(Crabb 56). In addition Nde, Bindiga, Lenatai have túi, (Thomas 29).

Ejagham

$o-t \ddot{i i}$ "smith"(Mansfeld 112-14)

\footnotetext{
${ }^{11} \mathrm{~L}$ stands for low tone, $\mathrm{H}$ for high tone.
} 
Ejagham

Ikom

Bankong (Abo 2) besha-o-tüi "bellows" nshong-otüi "to forge" and ntai -otüi "anvil" = "stone of smith"(Mansfeld 11214) -wole, -wore ${ }^{12}$ -wol- "to forge" (Guthrie CS 1861)

\section{Bantu A50-A60 -lun, -dun "to forge"}

Nen

Nen

Nen

Yambasa

Mvanip (Mambiloid)

Vute (Mambiloid)

Kam

Bitare (Yukutare)

Abo

Somrai

Laka (Lakka)

compare to Mpongwe -lun "to forge" (Van Leynseele, Steward 424)

bi-lun "finery furnace"

mu-lun (sg) i-lun (pl) "blacksmith"

-dun "to forge" (Guthrie CS 1861)

\section{Adamawa Region}

wo-wuro "blacksmith" (Meek, 1:582)

wúr "forge" and tó-wur "smith" (Guarisma 107)

a-tul "smith" (Meek 2:548)

n-tula "smith" (Meek 2:578)

cuna "smith" (Meek 2:584)

-ula (bu, ma) "smith" (Lukas 85)

Possibly

do\#u dze ko\#nda mbol "smith"(Tessmann 75)

tuna "to forge" and Kwa e-tuna "iron"(Talbot 430)

\section{Ubangian}

Gbaya Yaayuwee

düi "to forge"(Noss 14)

Gbaya Lai (Dooka) dó\#é "to forge"(Noss 14)

Gbaya Mbo\#domo dó\#l, dol "to forge" (Noss 14; Moñino 114)

Gbaya Kara $d o i$ "to forge" (Moñino 114)

Gbaya Biyanda

doe "to forge" (Moñino 114)

Gbeya

doi "to forge (Moñino 114)

doy (Gaud 348)

Manja

do\#lo\# "to forge" (Moñino 114)

Manza

dwala "to forge" (Moñino 114)

Bangando-Ngombe dara "to forge"(Moñino 114)

Bofi $w i+d u l a$ "to forge" turu "the art of forging"

${ }^{12}$ The clear identification of the Bankong form as a reflex of "túd also supports the inclusion of Ikom, Vute, and Mvanip with reflexes of this form. 
Barambu at Amadi

Barambu at Poko

mätúlé "smith" (Tucker/Hackett 254)

mútúlé "smith" (Tucker/Hackett 255)

The last three attestations are almost certainly loans from a neighboring Bantu languages, but the Gbaya forms are not.

\section{Elsewhere?}

Ahlo (Togo) du "iron" (Westermann 291)

No wonder that Guthrie deduced that this sort of evidence proved that forging was PB. Yet his conclusion has been convincingly rejected by de Maret and Nsuka, who showed that the meaning of *tud-in a number of languages from different parts of the sub-continent was a general one, meaning "to beat, to strike, to hammer." That includes forging, but is not restricted to it. Therefore the original meaning seems to have been "to hit repeatedly" and only included "to forge" later, when this activity was introduced. This interpretation is strengthened by semantic analogies elsewhere in Bantu (Klein-Arendt 130-31) and outside of Bantu-for example, in Bwatiye (Camba) where bül (LH) and púko both mean "to forge" but bül (LH) also has the general meaning of "to beat, to kill" and púko "to lay down, to pour in, to put away, to weave" (Pweddon). Proto-plateau TUAD "to beat" and TUAM "iron" are equally suggestive.

Still, as the Bwatiye case and PB both show, there was more than one verb meaning "to hit" or "to strike" and hence there were several possibilities from which to derive a verb "to forge." The fact that only one and always the same one. namely *túd, was chosen does point to a single common origin for the derivation. Given its presence in various Bantoid groups as far away as Jarawa and Kagoro, including the region which was once the heart of the iron-using Nok culture, one must conclude that this form with the meaning "to forge," entered the Bantu-speaking areas from the northwest, and that it reached Ubangian from the west (Klein-Arendt 229, 244; contra Ehret 140-44). The word thus spread from west to east. Its attestation in Sabaki shows that it spread as far as the shores of the Indian Ocean.

In addition to the distribution listed, a separate innovation from ${ }^{\circ}$-túd"to forge" occurred in Wide Bantu with the meaning "iron," and was also adopted in Ekoi, Bafia, and Vute. It is obvious though that all these forms are related to the nearby Ekoid languages -t $\hat{u} i$ etc. "to forge" and to a Bantu '-túd- "to forge." In fact Ludwig Gerhardt (1998:13, 17) has documented the regularity of the formal correspondences between Mungaka, Proto-Grassfields, and Bantu ${ }^{\circ}$-túd-. The known reflexes are the following: 


\begin{tabular}{|c|c|}
\hline Proto-Grassfields & -ténV (Gerhardt 1998: 13, 17) \\
\hline Bafia & $-t e i$ \\
\hline Bati & $-\operatorname{ten}$ \\
\hline Kom & $-t e n$ \\
\hline Bamum & -tena \\
\hline Bum & $\begin{array}{l}\text {-tei (if the words for "iron and "stone" in Koelle's } \\
\text { Mbe are transposed as they appear to be) }\end{array}$ \\
\hline Mungaka & $\begin{array}{l}\text {-tun "iron" ndun "iron tools" (Stöckler 365); } \\
\text { Gerhardt 1998:13, 17) }\end{array}$ \\
\hline Mbudikum (Widikum?) & $\begin{array}{l}\text {-tin, -tü, (Johnston \# 230-31, p.814); e-tu "iron" } \\
\text { (Westermann 291) }\end{array}$ \\
\hline Ekoi & tu-na "iron" (Westermann 291) \\
\hline Vute (Mambiloid) & $\begin{array}{l}t \tilde{u} \text { "iron" (Guarisma } 107,74: \text { a later introduction } \\
\text { than wúr "to forge" but ultimately from the same } \\
\text { source) }\end{array}$ \\
\hline Bamileke-Bamenyam & - tiin \\
\hline Balu (Beli) & -tinera \\
\hline Fut & -tine \\
\hline Nwala & - tio \\
\hline \multicolumn{2}{|l|}{ Bagba (Abragba near } \\
\hline Nde is Ekoi) & $-\operatorname{tin}$ \\
\hline (Ndop & lini?) \\
\hline (Ndop-Tumu & line?) \\
\hline
\end{tabular}

Given the presence of a form $t u$ "iron" in a few other West African languages that may be related to ${ }^{\circ}$-túd "to forge" we must wait for further study before any further conclusion can be reached. ${ }^{13}$

\section{V}

The third word in this set about forging is *-(j)o\#ndo 9/10 "sledgehammer." This word usually designates an elongated mass of iron fashioned into the shape of a huge flatheaded nail that was used during the forging process both as a hammer and as an anvil wherever this tool was used. In many places it was also an object of considerable value and/or an emblem of blacksmiths. Moreover, the word was also used elsewhere to designate a heavy hammer. Its distribution in the Bantu languages is practically continuous and has been well plotted by Guthrie, de Maret/Nsuka, and Klein-

${ }^{13}$ Westermann 291, lists a number of other West African words for iron of which the following share a root $-t u$. They occur in Kyama, Alagiã, Likpe, Ahlo, Kposo, Bulom(two forms), Temne, and possibly in Tafi, Senufo (Tagwana), and Nafana. 
Arendt. ${ }^{14}$ It encompasses the whole range of these languages, as well as the following non-Bantu ones.

\section{Non-Bantu ${ }^{\circ}-(j)$ o\#ndo "sledge hammer"-Map 2}

\section{Jukunoid (Shimizu 304)}

Proto-Jukun-M

"ngyo "to forge"

Ashuku

ngyo "to forge"

Kporo

$y u$ "to forge"

Jukun lects

$y u$ "to forge"

nje "to forge"

$t a+n g y u$ "blacksmith"

$n g y o, n g y u$ "forging"15

\section{Bantoid,Wide Bantu and A60, A 43, A72, A 75}

Tiv

Banyang

Mungaka

Bafia

Bafia

Bafia

Basaa

Ewondo

Fang nondo $(\mathrm{sg})$ inyondo $(\mathrm{pl})$ "sledgehammer"

ndoob "sledge hammer" (Mansfeld 288, loss of first syllable)

ndun "smith's tools"(Stöckler 235)

ndon 3 (Guarisma 86)

ndìn (Tessmann 1934:146)

ron 5/6 (Guarisma 92)

n-jong (Schürle)

ngondo/be

nno\#n, ngóne "anvil"

\section{Ubangian}

Bak

Munzombo

Nzakara

Zande Abandiya

at Bondo njö\#njo var. njo\#njo\# "anvil"; nyo\#njo "iron."

nzo\#lo\# "sledge hammer" (Wambat:227)

dúnda "ingot, anvil "(Lukas 13; Tucker/Hackett 252)

dunda "ingot' (Mopila 75) ${ }^{16}$

${ }^{14}$ Guthrie (CS 706, ps 515, CS 965, CS 2126, CA 2171 and 1:118 \# 73.13); de Maret/Nsuka 51-52.

${ }^{15}$ In addition, Jukunoid $-j u$ "smith," might well be related to this. In contrast with Banyang, which dropped the first syllable, Jukun languages drop their second syllables, and we would certainly include it in the list if its meaning was "sledgehammer," but it is not and I have disregarded these forms.

${ }^{16} \mathrm{~A}$ loan from one of the Boan languages is probable in this case. Note also that for Klein-Arendt (220) the word for "iron bell" ngwa, corresponds to "-ngwa "iron," in 
Mamvu and Mangutu ndundu "ingot" (McMaster 35; Van Geluwe 1957:42)

The Ubangian attestations have been explained as derived from neighboring Bantu languages by later diffusion. Indeed, all linguists before Nsuka and de Maret also reconstructed *-(j)o\#ndo as PB. But Nsuka and de Maret argued that the meaning of this word could not be PB because otherwise it would prove that metallurgy was introduced by PB speakers, which they judged to be impossible. Therefore they posit-but without any evidence-that the form was $\mathrm{PB}$, but that its original meaning was "hammer" in general. That is of course circular reasoning (de Maret/Nsuka 53; Nsuka/de Maret 738). Yet they may be right. There is some linguistic evidence to doubt that ${ }^{\circ}-(j)$ o\#ndo "sledgehammer" was PB, namely, the presence of no fewer than six different variants of reconstructed forms. That is unlikely for a PB form, where each variant would refer to a different dialect, but is to be expected in a loanword, where transfers often yield skewed forms. Hence the evidence suggests that ${ }^{\circ}-(j)$ o\#ndo is an ancient loanword rather than a PB form. In a few cases for which there are secure data, the evidence indicates that this is precisely what happened, but the question will be settled only when a systematic test of all the reflexes has been undertaken. In the meantime we can consider ${ }^{\circ}-(j)$ o\#ndo to be a loanword and derive a sequence of initial consonants and classes from an initial $-n j$ in class 9 or 3 . Its almost universal spread is explained by the practical usefulness of sledgehammers for smithing.

Moreover the presence of a reflex nydono (spelled Nhdono) in Manja (Gaud 348) far to the north of the Bantu borderline in the Central African Republic gives food for thought, even though the spelling is an error for the form dono\# (Renouf-Stefanik 336; Vergiat 106), which is obviously related to Ngbaka (RDC) and Gbaya Yaayuwe dono. This forms suggests a proto-Gbaya ${ }^{*}$ dono\#, in which case ${ }^{\circ}-(j)$ o\#ndo and this ${ }^{*}$ dono\# are probably ultimately related, and the Manja form would not be a direct borrowing from a Bantu language to its south .

As the evidence stands then, "- $(j)$ o\#ndo "sledgehammer" entered the Bantu speaking area from the northwest, presumably before $400 \mathrm{BCE}$. In addition, a closer examination of the stylistic differences between iron sledgehammers might well yield more detail on ${ }^{\circ}-(j)$ o\#ndo's pattern of diffusion.

The cumulative evidence of these three words shows unambiguously that ironworking did not arise independently in Bantu-speaking Africa, but was introduced from adjacent regions of West Africa, probably from the middle belt of Nigeria and Adamawa. Ironworking technologies then

Boan; nwã "iron," in Ngbandi; ngóá in Komo; and probably ngua in Tooro and Amba. Could these be related to konga, kunga "iron, metal" in the Ekoid languages of the Ogoja area (Crabb 75;Koelle 82-83)? The word forms allow it by regular sound correspondences, but given the distance involved I hesitate to do so without further data. 
entered the Narrow Bantu-speaking area both from the present Central African Republic and from regions north and west of the Cameroon grasslands, and subsequently spread gradually and over a wide front to reach most of the then Bantu-speaking area by the last centuries BCE.

This was not the only period when words related to metalworking diffused between non-Bantu languages in the northwest and adjacent blocks of Bantu languages. Obvious among these are ${ }^{\circ}-k o \# m b a$ or ${ }^{\circ}-k u m b o ́ \#$ "bellows, "-ceni "iron" and '-kúba 5/6 "smithy" and its relative ${ }^{\circ}-k u ́ b a 1 / 2$ "smith." I do not discuss these words here because their distributions are only regional and thus indicate that, whatever their possible antiquity, their diffusions are more recent, and hence not directly relevant to a search for the initial introduction of iron-working in the Bantu speaking area.

I now turn to a few other words that have seemingly very large distributions, but are innovations from within Bantu, and hence of later origin than the set we just examined. Still, since their reflexes are widespread, they probably are very old innovations. This set includes "-táde 14 "iron, and "-kélwa "tuyère." I exclude a separate set consisting of "geda 7/8 "iron," "-vukuta "to smelt," "to blow the bellows," and "-vuba 3/4 "bellows," despite the fact that Guthrie, Nsuka/de Maret, and Ehret have all attributed very large distributions to their reflexes, and hence held them to be very old. But they have erroneously conflated the reflexes of different words into a single one, rendering the distributions spurious. In reality, the spread of the true reflexes of these words is restricted to the eastern half of the Bantu-speaking area. I return to them later on.

The form "-táde is well known to Bantuists with the attested meanings "stone," "bloom," “iron," "metal," “iron ore," "rust," "copper," and various sorts of iron objects. Reflexes with the meaning "stone" are found in practically every corner of the Bantu-speaking area and well beyond. ${ }^{17}$ Not only is the word PB, but it is much more ancient since it is also ProtoBantoid, Proto-Benue-Congo, and Proto-Volta-Congo. ${ }^{18}$ This explains why related reflexes occur in Adamawa-Ubangian languages, for instance, Gbaya ta. Every scholar except Guthrie accepts this word with the meaning "stone" as PB. Guthrie refused to do so because there exists another PB form for "stone," but that argument is not acceptable. After all, one expects Stone Age PB-speakers to have had several words relating to stone/s. His suggestion is that *táde $5 / 6$ originally referred to iron ore,

${ }^{17}$ Guthrie CS 1642 , gives only a few reflexes. Since this basic word occurs in the standard lexicostatistical list Schadeberg (Phillipson/Nurse, 162) gives a reliable distribution, from which it appears that only the northeast (zones $E$ and $G$ ) of the Bantu area lacks reflexes. See also Klein-Arendt 469-70.

${ }^{18}$ See Piron 378-379 for attestations beyond Bantu. 
although most of the known reflexes for "iron ore" and "bloom" are in class 14 and clearly derived from the form in class $5 / 6$ with its meaning "stone." As lists of reflexes are already available (Guthrie CS 1642, 1643, 1644 and vol I, topograms 25, 26; de Maret/Nsuka 45-46; Klein-Arendt map and lists 468-74), and as the shape of the reflexes everywhere poses no problems (-táde, -tále, -tári, -rale, -rhalé, -thale, -dale), we only list the languages in which reflexes have been found as follows.

\section{I ${ }^{\circ}$-táde 14/6 "iron-ore"(starred when in other classes)-Map 3}

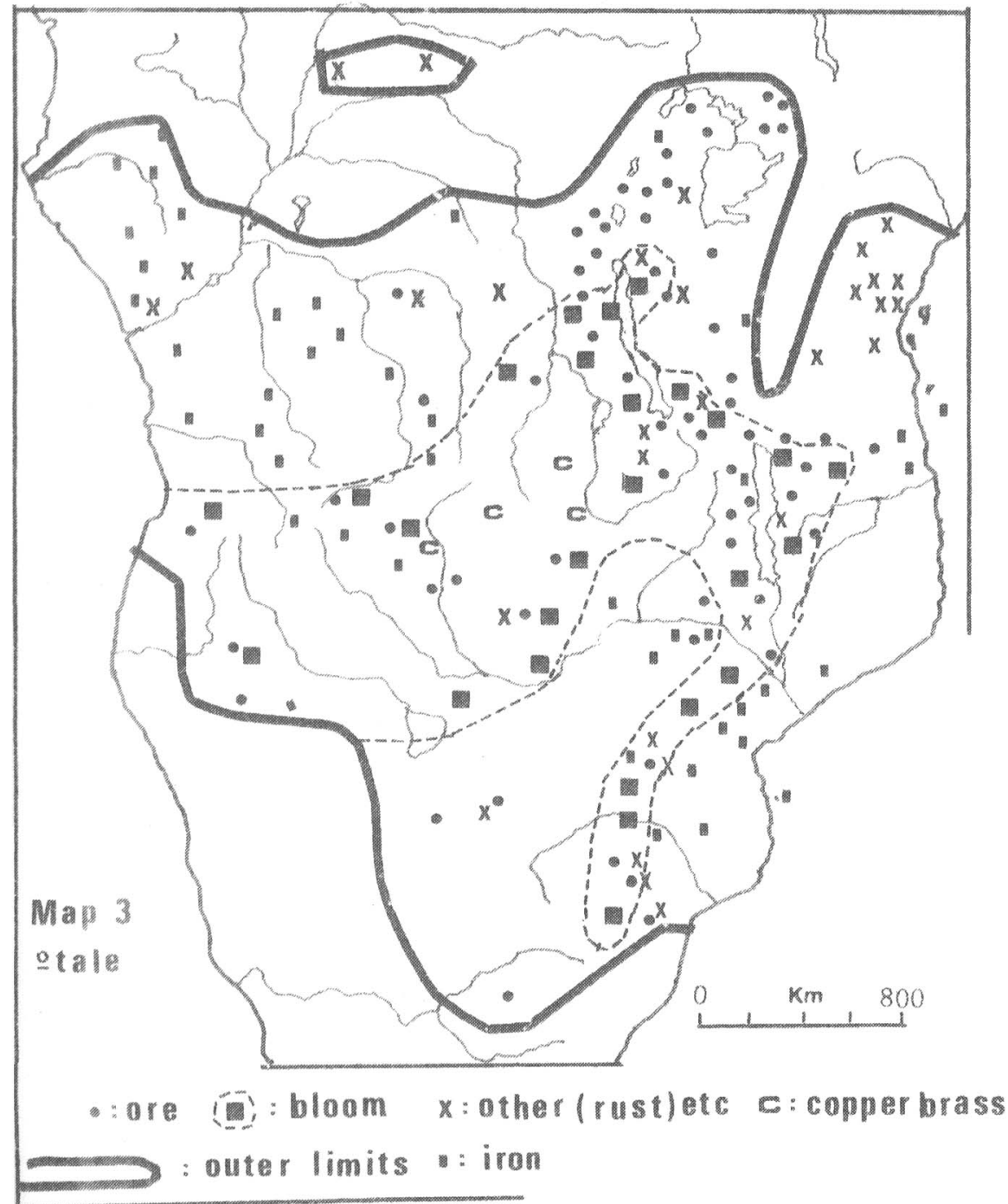


Bangubangu, Nyanga, Konjo, *Nande, "Hunde, Tembo, Shi, Rwanda, Rundi, Fuliiro, Ha, Nyoro, Toro, Nkore, Kiga, " Ganda, Gisu, Bukusu, Saamia, Luhya, Nyamwezi, Sumbwa, Kimbu, Wungu Ndamba, Kinga, Lozi, Luyi, Luba, Hemba, "Bungu, "Mambwe, "Namwanga, "Iwa, *Ngoni, "Tonga Lake, *Tumbuka, "Nyanja, Nyakyusa, Tabwa, Bemba, Lenje, Ila, Yao, Matumbi, Nyungwe, Sena, Ngindo, Shona Karanga, Tswana, Kgalagadi, Pedi, Lovedu, South Sotho, Swazi, Kwanyama, Ndonga, Umbundu, Cokwe, Lwena, Kongo, Salampasu, Bushong

\section{II '-táde 14 "rust"}

Bushong, Matengo, Shona-Karanga, Venda, Tswana, Pedi, Lobedu, Swazi

\section{III "táde 14/6 "bloom" (starred when in other classes)}

Cokwe, Lwena, Umbundu. Bangubangu ("bloom" or “iron”?), Holoholo, Rundi, Hemba, Luba Katanga, Tabwa, Lenje, Tonga, Ila, Fipa, Nyiha, Ngoni, Matengo, Pangwa, "Nyanja, Shona-Zezuru, Manyika, Shona Karanga, Swazi, Yeyi, Kwanyama

\section{IV "-táde 14/6 "Iron. Metal,"}

Kela, (-dadi), Vili, Kongo (also "metal"), Mbala dialect 09, Pende, KongoDinga, Rund, Ndembo, Nyemba, Lucazi, Mbunda, Nyamwezi, Lake Tonga, Cuabo (also Makhuwa?), Nyungwe, Sena, Manyika, Kunda, Ndau, Bazaruto, Ngoni (Gaza), Shona-Karanga, Venda

$$
\text { V -táde 5/6,7/8, 11/10 “iron,” }
$$

Tsayi, Nzebi, Duma, Mbete, Ndumu, Tege, Mbuun, Pende, Holo, Kimbundu Imbangala, Songo, Huku, Makonde, Mwera, Mabiha (Mavia), Nyai, Manyika, Karanga

\section{VI ${ }^{\circ}$-táde 5/6, 7/8, 11/10 "iron object"}

All attestations of the meanings "tax," medal" or "money" in RDC and in Angola are of colonial vintage and are omitted.

With the meaning "axe:" Yombe, Tio; with the meaning "knife:" Bobangi, Ngombe; with the meaning "spear:" Nkore, Rundi, Gogo; with the meaning "metal wire:" Mambwe, Bemba, Ila (iron binding for staff), Venda; with the meaning "thread, fibre:" Shona-Karanga; with the meaning "iron bracelet:" Shi; with the meaning "smithy:" $\mathrm{Ha}$; with the mean- 
ing "arrow, arrowhead:” Kamba, Segeju, Mijikenda, Taita/Dabida, Taita/ Sagala, Pare (Asu), Shambala, Bondei, Zigua

\section{VII ${ }^{\circ}$-táde 14, "copper, brass"}

Lamba /Lala, Nkoya, Mwenyi

$$
\text { VIII }{ }^{\circ} \text {-táde 3/4, 9/10 “slag” }
$$

Fipa, Nyanja

All ${ }^{\circ}$-táde words related are derived from PB *-táde 5/6 "stone" and its ancestors as far back as Proto-Volta-Congo. But no reflexes of ${ }^{\circ}$-táde "iron ore, bloom, iron, iron object etc." are found outside Bantu or in the northern most parts of the Bantu-speaking areas except for "knife" in Bobangi and Ngombe. Therefore ${ }^{\circ}$-táde was coined somewhere in the middle latitudes of the Bantu-speaking area. To find out more about the various shifts in meaning from "stone," we first consider the reflexes in class 14 with the meanings "bloom" and "iron ore" and find a single continuous distribution for "bloom" in the central part of the Bantu-speaking areas below $4^{\circ} \mathrm{S}$., surrounded and partly overlapped by one for "iron ore" that includes whole regions in the great Lakes and the southeast and eastern Angola as well as more isolated occurrences in Salampasu, Bushong, and Kongo. ${ }^{19}$ Patterns of concentric distributions frequently occur when a new feature is innovated in a word in the center of an older diffusion area and begins to spread outward from there. The features of the latter then survive on the periphery. Hence "bloom" is more recent than "iron ore." Therefore the shifts in meaning of "-táde were: "stone" $5 / 6>$ "ore" 14 , probably meaning "crushed iron ore prepared for the furnace" > "bloom" 14. The derivation "furnace" $>$ "rust" is separate from this. The shifts from "bloom" > "slag" and "bloom" > "iron," "iron object" > "metal in general" and even > "copper" lie for the most part on the peripheries of the distribution area and resulted from several different local shifts in meaning.

The shift of meaning from "stone"> "ore" can only have occurred in a place where ironworking was already practiced. Given the distribution patterns for "bloom" and "iron ore," as well as the general direction of the spread of ironworking technology attested by the words examined in the first part of this essay, this shift must have taken place somewhere on the northern border of the ${ }^{\circ}$-táde 14 distribution area, in a region where

${ }^{19}$ Note that, apart from Kongo, none of the attestations in the northwest refers to either "bloom"or "ore." Still, according to Dupré (101), bloom is ibanganga in Nzabi. 
-bo\#lo\# was used and where "-táde 5/6 "stone" was also common. ${ }^{20}$ The most likely location would be the eastern or southeastern border of the rainforests, more probably the latter. That is not far from the early archeological sites found in the southern Great Lakes region. At a later time the meaning "ore" then shifted to "bloom" somewhere west of Lake Tanganyika or in the Tanganyika-Malawi corridor and either ousted the earlier reflexes of ${ }^{\circ}$-bo\#lo\# "bloom" or, as in Nyiha, displaced the meaning of -bo\#lo\# to a later product in the production process. The distributions of attested reflexes in class 14 with the meaning "ore" and "bloom" are certainly incomplete, because one suspects that some lexicons that only gloss -táde 14 as "iron" actually refer to "bloom." Reflexes of "táde in other classes designate objects made out of iron or even other metals and are obviously later derivations. Such reflexes are only included here because in some cases their occurrence implies the likelihood that they are locally derived from "táde "iron," which was at one time in use in those local languages as well. Yet one suspects that in many instances such words for iron objects were imported from elsewhere along with the objects they designate.

Just as -táde came to be applied to "ore" only after iron-smelting accompanied by ${ }^{\circ}-b o \# l o \#$ and other words from its set reached the region from the north a similar process led to ${ }^{\circ}$-kélwa $9 / 10$ "tuyère" or/and "drain for slag" to which we now turn (Klein-Arendt 147-51, 604-07, 610-17, text and maps). Although relatively few lexicons carry this word, the available lists of reflexes is reported from every Bantu-speaking region but the northwest. So far we have not found it outside Bantu and we are unlikely to do so, for the word has a clear Bantu etymology. It is derived from the ancient PB verb *-kéd- "to strain, to filter." Its situation and distribution area are rather similar to that of ${ }^{\circ}$-táde except that in this case the end vowel is $-a$ in the more western and $-w a$ or $-o$ in the eastern reflexes. Since lists of reflexes are readily available (de Maret/Nsuka 55-56; Klein-Arendt 612-17). I cite only the languages in which they are found.

\section{○-Kéla "tuyere" 9/10 "drain for slag" 9/10-Map 4}

Kinga, Umbundu. Cokwe, Lwena, Nyemba, Nyaneka, Luba Katanga, Luba Kasai, Kaonde, Ila, Tonga, Namwanga, Bua (McMaster 163), Lebeo, Dzamba, Kongo, Yaka (Plancquaert 15)

\footnotetext{
${ }^{20}$ According to Van Noten, populations in Uélé continued to make handaxes out of oligist (an ironstone) even after they were working iron.
} 


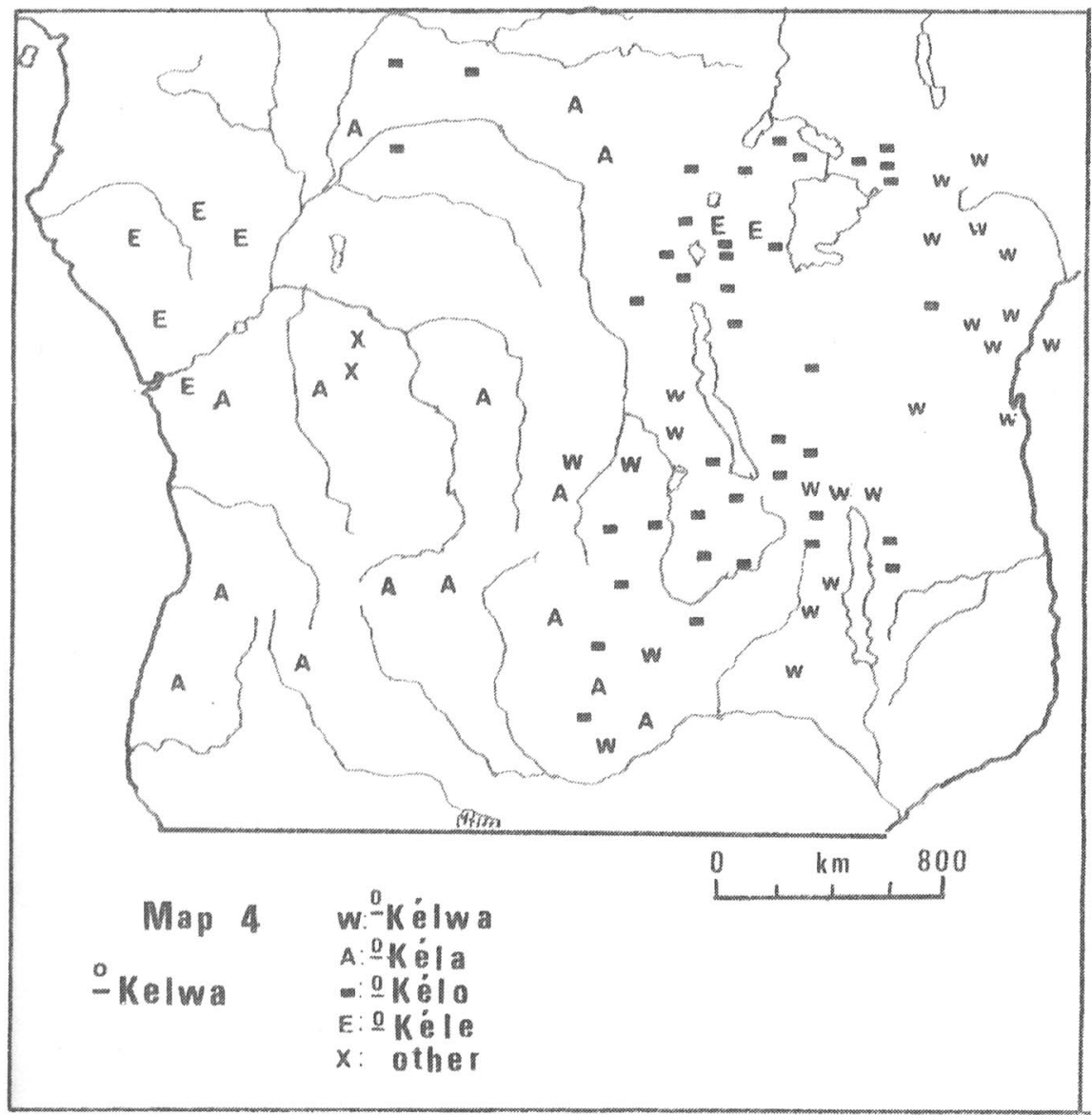

-Kélwa "tuyere" 9/10 "drain for slag" 9/10 (Klein Arendt 337-38, added)

Kikuyu, Embu, Kamba, Mbeere, Igembe (Brown 174), Mijikenda, PareAsu, Shambala, Swahili, Kaguru, Kinga, Holoholo, Hemba, Luba Katanga, Nyiha, Nyakyusa, Lenje, Tonga-Zambezi, Tonga-Malawi, Tumbuka, Cewa

\section{¿-Kélo $(u)$ “tuyere" 9/10}

Ngombe, Tetela, Lega Pangi, Marachi (Brown 174), Wanga (Brown 174), Hayo (Brown 174), Ganda, Nyoro, Toro, Haya, Nande, Hunde, Havu, 
Kiga, Shi, Rwanda, Rundi, Ha?, Chaga (Gutmann's), Nyamwezi, Sanga, Tabwa, Mambwe, Fipa, Lungu, Namwanga, Nyiha, Iwa, Pangwa, Matengo, Tumbuka, Bemba, Bisa, Lala, Lamba, Aushi, Ila, Tonga-Zambezi

-Kéle 9/10, "tuyere"

Nzebi, Teke (Obenga 1985:322), Kukuya, Kongo, (but nkélo 9/10 "funnel") Bobangi (Obenga 1985, 321 "slag"), Nkore, Kiga

\section{Other derivation $s$ from ${ }^{\circ}-K_{e} d$}

Suku -keshi 6 "slag" (Lamal 88+ Obenga 1985:323) and Hungaan -kese, 6 "slag."

The forms all derive from *-kéd- "to strain" (CS 1030), a verb that is itself not $\mathrm{PB}$, but arose soon after the separation of the northwestern Bantu languages in which it has no reflexes. This form with a high tone and reflexes for $k$ - as first consonant should not be confused with *-ged"to flow"(CS 800) with low tone and initial $g$-. In many languages the difference between reflexes from *-kéd-and *-ged-becomes minimal and can be reduced to a single tone. For instance, in Bushong ngél 3/4 "salt" derives from "-kéd-, while ngel 9 "downstream" stems from -ged-. Similarly, in Ila -éla 7/8 "tuyère" stems from "-kéd- and -ela 7/8 "iron" from *-ged-, where the difference in tone is the only distinction between them. Unfortunately, only a minority of lexicons indicate tone, so that in many cases the attribution of a reflex without tone to the meaning "tuyère, drain for slag" as opposed to "iron" is only indicated by the noun class. It is not surprising then that Klein-Arendt (148-51), who did not pay attention to tone throughout his study, hopelessly confused the etymologies of -kélwa "tuyère," "drain for slag," from "to strain" and -gela "iron" from "to flow."

The verb *-kéd- (CS 1030) first yielded the noun *-kédo 9/10 "funnel, strainer" (no CS), that is, the funnel or filter used for straining the vegetable ash of plants rich in salt, a very common practice and one that accounts for another fairly widespread word derived from the same verb with the meaning "vegetal salt" *-kéde $3 / 4$ (CS 1031). As the exploitation of salt is undoubtedly older than the working of iron, these derivations must be older than -kélwa $9 / 10$ "tuyère," which is yet another derivation from the same verb. The geographic evidence supports the reconstruction Bennett (124) made on phonetic grounds that the original derivation from the verb *-ged was ${ }^{\circ}$-kélwa $9 / 10$ because most of the $-w a$ reflexes are peripheral to the whole distribution and hence the older form. 
Now ${ }^{\circ}-k e ́ l w a$ is best derived from its verb as a passive noun referring either to the process of filtering or to the filtrate. Hence it first referred to the draining of the slag, not the forcing of air through a tuyère. The shift of meaning may have occurred because the same sort of tubing was required for both purposes. We don't know and since none of the available general dictionaries and lexicons differentiates between tuyères (tubes to add air) and drains for slag,we don't even know whether in fact the same word was used for both types of objects or not.

The word ${ }^{\circ}-k e$ elwa was obviously invented when ironworking reached a Bantu-speaking region and created the need for the notions "drain for slag" and "tuyère." The distribution of this form of the word suggests it was most likely coined between the Ubangi river and the bend of the Congo river-that is, further north than ${ }^{\circ}$-táde was and presumably earlier.

Later, ${ }^{\circ}-k e ́ l w a$ mutated into the forms in -o (mostly in eastern languages), $-a$ (in the western languages), and $-e$ (by assimilation of the last vowel to the first one). When the later form in -o developed somewhere in eastern Africa, it erased the distinction between "funnel, strainer" and "tuyère" and turned them into a single word. Where the ending in - $a$ prevailed, this did not occur. Thus in Kongo, Umbundu, and Bobangi, for instance, one finds reflexes in the same languages for both ${ }^{\circ}$-kéla $9 / 10$ "tuyère, slag" and the older ${ }^{\circ}$-kelo, 11/10 "funnel." Finally, the $-e$ forms clearly result from the assimilation of the last vowel to the first one. This innovation apparently occurred twice independently-in lower Congo and in the Great Lakes area.

Given the formal and semantic deficiencies of the data that have been mentioned, we cannot draw further inferences or conclusions from the distribution or the semantic shifts relating to ${ }^{\circ}-k e$ élwa until more and better data are in hand.

\section{VIII}

We now discuss a set of three words whose distributions cover only a single region, albeit a very large region, in eastern, southern, and parts of central Africa. Since they are regional, we would not consider them here except that a non-Bantu origin in northeastern Africa has been proposed for all three words by either Ehret or Klein-Arendt. Still, as we shall see, I think that all three are innovations from within Bantu and can stand as examples for several other similarly large regional innovations elsewhere. Indeed a few of the latter, such as ${ }^{\circ}-k u m b o / k o \# m b a$ "bellows," ${ }^{\circ}$-ceni "iron," and "-kúba "smithy, smith," spread over sizable regions in the northwest that include both Bantu and non-Bantu languages.

The first of these three words is ${ }^{\circ}$-gela 7 "iron." Guthrie (CS 800) de Maret/Nsuka (44), Ehret (126-28), and Klein-Arendt (218) all erroneously 
conflated its distribution area with that of northwest Bantu reflexes ${ }^{\circ}-k e$ or $^{\circ}-c e$, but Meeussen did not. As it happens, those reflexes all belong to a regional form ${ }^{\circ}$-ceni "iron," which includes many non-Bantu languages and may well be Bantoid in origin. Ehret and Guthrie concluded from the distributions they posited that ${ }^{\circ}$-gela was the initial word for iron in Bantu. But for Klein-Arendt (218-21) it is younger than ${ }^{\circ}$-táli 14 "iron," and the Bantu reflexes of ${ }^{\circ}$-gela derive from ${ }^{\circ}$-sibila, itself a loan from an East Kushitic language. We cite all known reflexes rather than rely on those given by the authors because the latter often confused them with reflexes from ${ }^{\circ}$-kéla. (Sources for these reflexes are only cited if they do not occur in standard lexicons or in Klein-Arendt 488-90.)

o-gela 7 "iron, metal" unless otherwise specified-Map 5

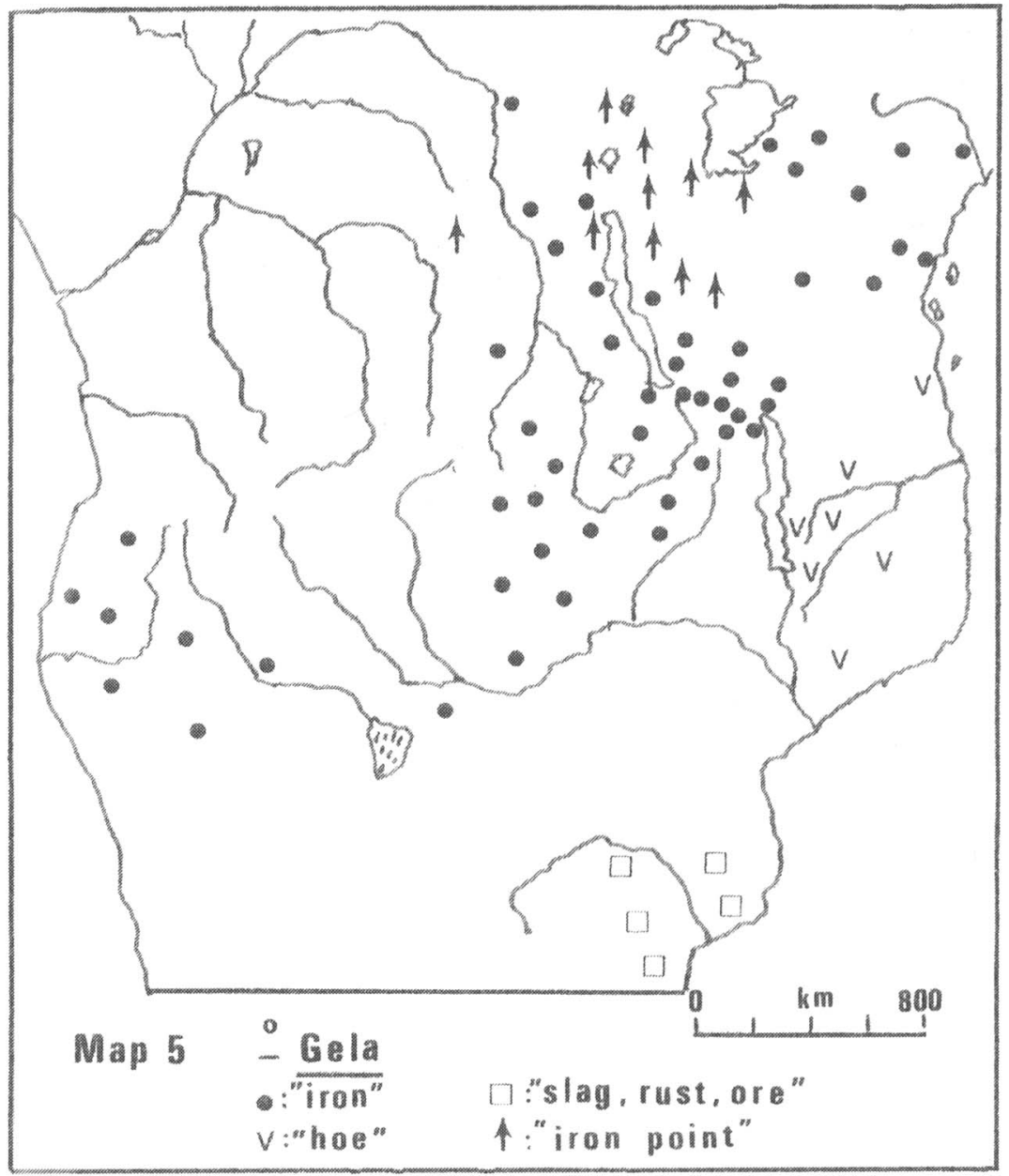




\section{Northeast}

Pokomo

Giryama

Embu

Kikuyu

Kikuyu

Kamba

Segeju

Taita

Pare (Asu)

Sonjo

Kwaya

Sandawe (not Bantu) -keral-cera 7/8 (Nurse/Hinnebusch 668)

-gera 7/8 “iron weapon"(Nurse/Hinnebusch 668)

-gera $7 / 8$

-gera 7/8 "iron"; in the plural "pieces of iron" -gera $12 / 13$ "small piece of iron"

-gea 9 "iron ore"

-gera $7 / 8$

-ria $7 / 8$ (cf. Kikuyu riba "hammer")

-gera 7

-gera 7 "hammer"

-yera 7 "money"

keeya + carver of "blacksmith" (Kagaya 39)

\section{Tanganyika-Malawi Corridor}

Fipa
Wungu
Proto-Nyika
Proto-Mwika
Lungu
Mambwe
Wanda
Namwanga
Nyiha
Nyiha
Lambya
Malila
Safwa
Iwa
Nyakyusa
Nkonde

-ela $7 / 8$

-era $7 / 8$

-gela 7/8 (Nurse 1988:108)

-kela 7/8 (Nurse 1988:108)

-ela 7 "iron," "bloom"

-ela 7

-ela 7

-ela 7 "iron" "bloom"

-jela 7/8 "piece of iron, iron object;" also -jela 13, "splinter of iron"

-jela 7/8 "bloom"

-jela $7 / 8$

-jela 7/8

-jela $7 / 8$

- ela $7 / 8$

-era 7

-era 7

\section{East Central Bantu}

Holoholo

Tongwe

-gela 7

Kimbu

-jela 7

-gela $7 / 8$

Pimbwe

Enya

-ela $7 / 8$

-ea 7

-gela 7 


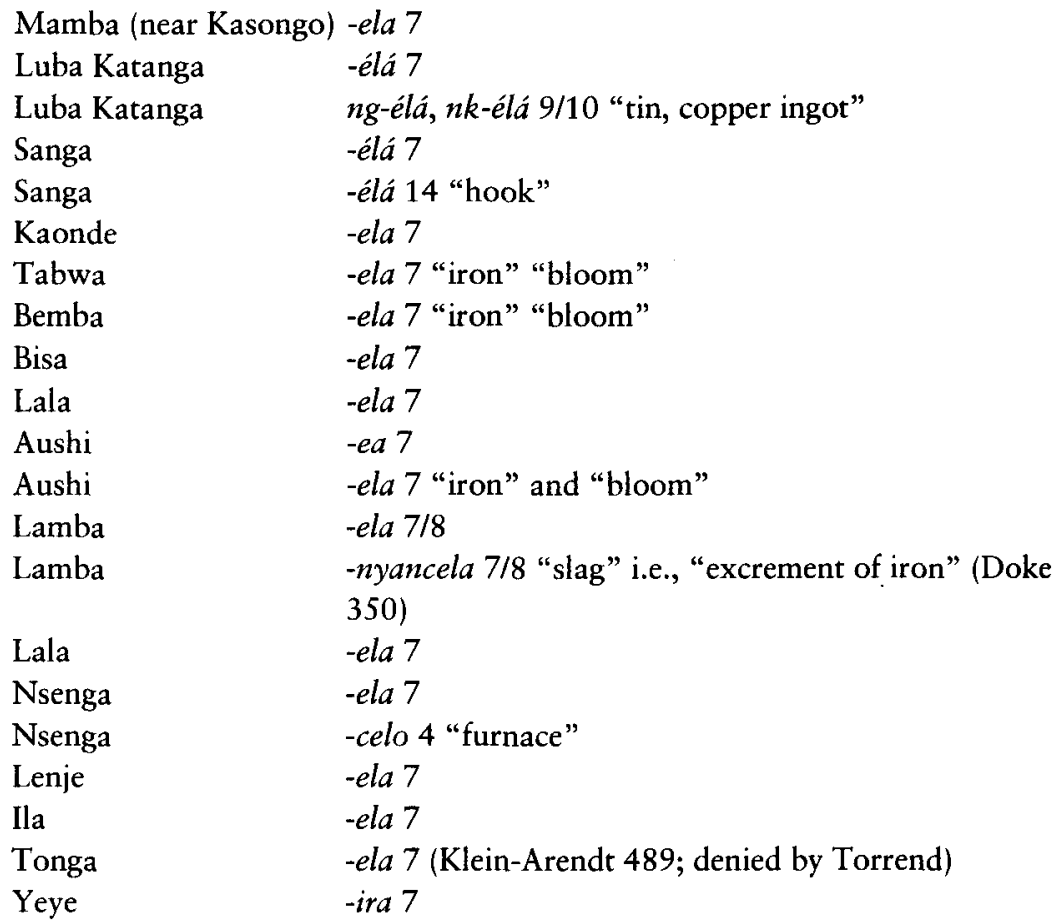

\section{Southwest Bantu: ${ }^{\circ}$-vela}

Umbundu

Nkhumbi

-vela $7 / 8$ (-bera $7 / 8$ in Nogueira 231)

Nyaneka

-vela $7 / 8$

-vela $7 / 8$

Kwanyama

-vela $7 / 8$

Ndonga

- ela 7/8 (oshyela)

Kwambi

Kwangari

-iera (> Portuguese "ferro"?)

-vera $7 / 8$

Great Lakes: "iron point" (Schoenbrun \#10 *-gèdà 3)

Nande

Kiga

Haavu

Shi

Vira

Rwanda

Rundi

Rundi -geé\#ra 3/4 "iron point, needle, puncheon" -gera 3/4 "iron awl" -gera 3/4 "awl, punch" -gera $3 / 4$ "pin, peg, needle, nail" -gera 3/4 "puncheon" -gera 3/4 "awl, puncheon" -gera 3/4 "stinger, needle point, puncheon" -gera 5/6 "fishing hook" 
Rundi

$\mathrm{Ha}$

$\mathrm{Ha}$

Haya

Sukuma

Nyamwezi

Tetela

Ngoni (Tanzania)

Matengo

Matumbi

Yao

Makhuwa/ Cuabo

Tumbuka

Copi

Tsonga?

Zulu

Zulu

SothoNorth

Phalaborwa

Venda -gera $11 / 10$ "hoe made out of stone; special spear point"

-gera 3/4 "iron point"

-gera 5/6 "fishing hook"

-gera 3/4 "iron awl, punch"

-gela 9/10 "spearhead"

-geela 9/10 "nail, needle" (Stern 163)

-de\#ngela 5/6 "nail"

\section{Southern East Coast: "hoe"}

-gela $5 / 6$

-gera $5 / 6$

-gela $5 / 6$

-jela $5 / 6$

-gila $3 / 4$

-vevera "to be sharp"

Southeast: "slag, rust, ore"

-rela 8 "rust"

-gwedi $9 / 10$ "iron ore"

-nyela 9/10 "slag"

-nyela 9/10 "pig iron (bloom), ironstone"

-nyaela 6 "slag" i.e., "excrement of iron"

-nyaela "slag" i.e., "excrement of iron"

-nyela "slag" i.e., "excrement of iron"

Its most likely etymology derives ${ }^{\circ}$-gela $7 / 8$ from *-ged- "to flow" as a regular nominal derivation (CS 798; Klein-Arendt 604, 610). Because of his unfortunate confusion between"-kéd- "to strain" and *-ged- "to flow," this etymology escaped Klein-Arendt. A generation ago de Maret and Nsuka (45) considered the etymology "flow" > "iron" to be less likely than others, but information gathered since then makes it by far the most likely. When considering this, one must enlarge the already large distribution in Bantu of *-ged-"to flow," by including *-geda 3/4 and *-gedi $3 / 4$ or 9/10 "stream"(CS 799, CS 801) as well as "-gede 9/10 "downstream," attested at least in Babole (nsáelo in Leitch 395, 396, 398: -ela is the root, not a suffix), Lingala, Bobangi, Sengele (Ikonya), Yans, Ding, Mbala, the Mongo languages, Tetela, Bushong, Kongo, Dinga, and Enya, as well as -celalthela "to pour," in the Sotho languages. With these inclusions the distribution of "-ged "to flow," is nearly Bantu-wide, although it is not 
reported from southern Angola and nearby Namibia, nor from inland Tanzania (but Nyiha has -jela 5 "a bit of ice, a hailstone").

It is also unreported in most languages of the northern fringe of the Bantu-speaking area west of the Great Lakes, including all of Northwest Bantu. Hence *-ged-was probably not PB, but was coined early on in one of the forest Bantu languages. Its meaning "to flow" is far more resistant to borrowing than "iron," yet the area covered by its reflexes far exceeds that of "gela $7 / 8$ "iron," which means that it must be much older than -gela and hence its source. The semantic shift involved is exactly the same as in French: "to flow > molten metal > cooled off metal." Hence *-gela $7 / 8$ must have referred initially to iron in a liquid or semi-liquid state, i.e., refined iron ready for forging, while all the other meanings in various reflexes must be later derivations.

This view is supported by the following data. Direct indications that -gela 5/6, 7/8 referred initially to "iron ready for forging" rather than to "bloom" are the use of the plural for "bits of iron" in Kikuyu, Luba Katanga, Bemba, Nyiha, and Mambwe. Indeed, people in southwest Angola borrowed the form of ${ }^{\circ}$-gela $7 / 8$ as $o-c i-v(y)$ ela. They perceived the plural $v y$-ela in the nearby southern Zambian languages as a root and added their own prefix. Hence the specific meaning of that plural can only refer to chunks or pieces of iron, ingots ready for forging, or iron objects, as it does in Nyiha and in Kikuyu. In Kikuyu the singular refers to a piece of iron, but not to a "lump of raw iron" (-kama, 7/8). In Lamba icy-ela is "iron/metal in a lump or ingot." Such cases make it clear that the original meaning was not "bloom," that is, a lump of raw, unrefined iron produced by a first smelting, but refers to a lump of iron refined by a second operation and ready for forging.

Apart from Nsuka and de Maret (45), no other author has considered this etymology of ${ }^{\circ}$-gela. Without any evidence at all, Ehret $(126-27,130)$ asserts that the word must be a loan from an unknown Central or Eastern Sudanic language. Klein-Arendt $(218,492-93)$ thinks that it originated as a loanword from Eastern Cushitic "-sibila "iron," as attested in languages such as Burji, Boni, Oromo, and Sidamo. That would imply that ironworking, or at least the knowledge of iron, was introduced independently a second time into the Bantu-speaking area, this time from northeast Africa. But he misinterpreted the reflexes of the type oxi-vela $7 / 8$ in southwest Bantu. Rather than being faraway reflexes of $a^{\circ}$-sibila that would parallel -sibia reflexes in Bukusu, Luhya, and Pokomo, as he thought, they, along with ironworking itself, were directly borrowed from $v$-ela 8 , the plural of $c$-ela 7 in southern Zambian languages.

The distribution area of ${ }^{\circ}$-gela $7 / 8$ "iron," is practically continuous and implies a spread from a single center somewhere between the Tana and 
the middle Zambezi rivers, since the forms in the southwest were borrowed from Zambia, whereas the ones in the southeast clearly derived from those further north, just as ironworking there was introduced from the north. The shift of meaning from "refined iron" to "sharp/pointed object" in the western Great Lakes region may be interpreted as a later development following the adoption there of ${ }^{\circ}$-(j)uma $7 / 8$ "item" or "precious thing" as the generic word for "iron."

As for the date of its coining, ${ }^{\circ}$-gela $7 / 8$ is neither PB (contra Guthrie CS 800) nor Proto-Eastern (or Proto-Mashariki), as Ehret (126-27, 130) claims. Ehret asserts that all the reflexes in today's Eastern Bantu languages show quite regular sound correspondences, which means that their common ancestors must have known the word, while they are irregular in all other Bantu languages and thus betray borrowing there. This claim is refuted by the cases examined by Nurse and Hinnebusch (668), that show that ${ }^{\circ}$-gela $7 / 8$ is not even Proto-Sabaki, since Giryama and Lower Pokomo borrowed it from one of the Central Kenyan languages. As the emergence of Proto-Sabaki dates some time after the first century CE or so, this transfer must have occurred at a later date. Yet ${ }^{\circ}$-gela $7 / 8$ was certainly used in the middle Zambezi valley by the first centuries $\mathrm{CE}$, since ironworking itself, along with the word, was introduced from there into southern Angola before or by $c a .500 \mathrm{CE}$. Hence its invention probably occurred some time during the last two centuries BCE and probably near the center of its present distribution, perhaps in the lake TanganyikaMalawi corridor, where the word is Proto -Nyika and Proto-Mwika.

To be complete, let me also mention that, quite apart from the ${ }^{\circ}$-gela "iron" we have discussed, one finds a similar word along the Congo River from Malebo Pool at least to the Aruwimi, with the meaning "iron, iron ore." The Bobangi reflex is certainly derived from "-ged- "to flow," but independently from the eastern ${ }^{\circ}$-gela, while the Teke words all appear to derive from "-(j)éde 3/4 "knife" (CS 1962), which Guthrie tentatively ascribed to PB on the basis of a relatively small but widely distributed set of reflexes. ${ }^{21}$

\section{Along the Congo: gele/i "iron," "pebble," "slag"}

Tio

Tege

Kukuya

Tio -ele 7/8 "pebble" (the only pebbles are slag) -eli 14 "iron" (from *-(j)éde 3/4 "knife"?) -ele 14 "iron" (from "-(j)éde 3/4 "knife"?) -eli 14 "iron" (from *-(j)éde 3/4 "knife"?)

${ }^{21}$ Guthrie lists Tetela, Buyi, Holoholo, Nyamwezi, Pare, Luba Kasai, Hemba, Bemba, Luyi, Umbundu, and Ndonga. These are plotted on Ehret's map 3 (148) and commented on 148-51. Many more reflexes can be added to Guthrie's list. Thus the addition of the Teke languages and Bobangi extends his spread to the northwest. 
[Ifumu

Bobangi

Basankoso

Ngombe

Ngombe

Lingala -elo 14 "iron" (from *-(j)éde 3/4 "knife"?)

-yeli 7/8 "iron, blade, weapon" (from *-ged- "to flow") -kele 6 "ore, pebble in river" -kbele 3/4 "pebble" -ngelo 6 "iron ore" -kele 5 ( $(i-)$ "ore"

\section{IX}

Next we consider ${ }^{\circ}$-vukuta "to work the bellows" and ${ }^{\circ}-v u b a 3 / 4$ "bellows," whose distributions are regional and to a large degree congruent with that of ${ }^{\circ}$-gela. As Klein-Arendt (590-93) lists most reflexes we only need to add the following:

\section{"-vúkuta "to blow bellows" and "bellows"-Map 6}

\section{Bantu}

Proto-Sabaki

Kamba

$\mathrm{Ha}$

Rundi

Nkore

Sukuma

Proto-Kilombero

Proto Southern

Highlands

Proto-Rufiji-Ruvuma

Proto-Nyika

Proto-Mwika

Lungu

Mwenyi

Mbukushu -vukut-and -vukuto 3/4 "bellows"(Nurse and Hinnebusch)

-vutuky-

-vugut- "to work bellows" and "to clap one's wings" -vugut- and -vugusi $1 / 2$ " blower of bellows" -jugut- and -jugutsi $1 / 2$ " blower of bellows" -rugut- and -ruguti 1/2 "the one who smelts iron"

*-vukutila (Nurse Sugia 108)

*-fukuta (Nurse Sugia 108)

*-fukutila (Nurse Sugia 108)

*-vukuta (Nurse Sugia 108)

*-vukuta (Nurse Sugia 108)

-vúkuta (Note the high tone)

-búkúta and -búkúto 5/6 "bellows"

-vukut-

\section{Ubangian}

Ngbandi

-vúkut $\hat{u}$ "furnace," "noise made by the big bellows," (Lekens verbo "smelt oven")

In general, ${ }^{\circ}-v u$ ukuta's nearly continuous distribution might seem congruent with that of ${ }^{\circ}-v u b a$ "bellows," albeit a little less widespread in the 


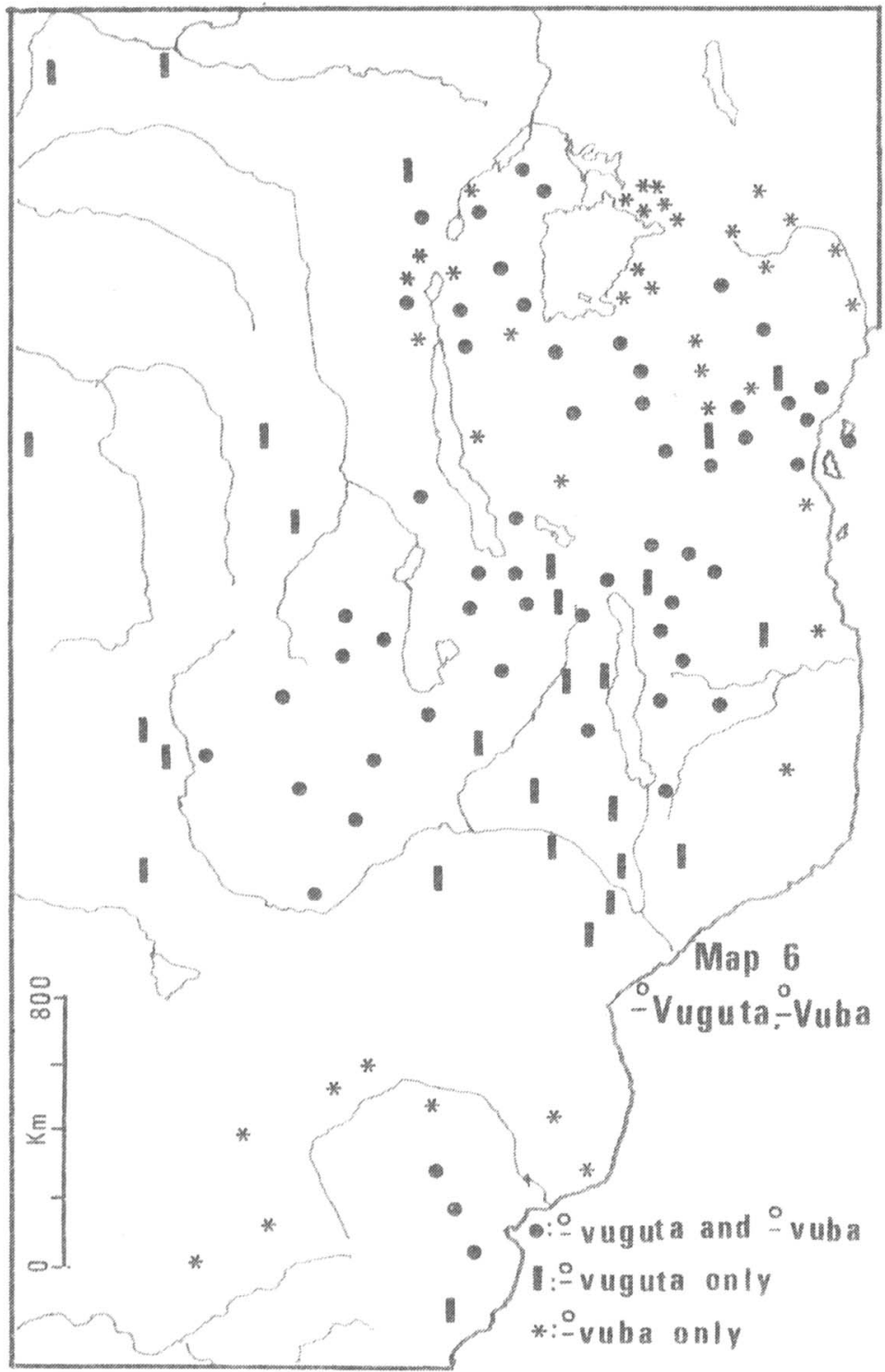

south, were it not for its separate presence in Ngbandi, well to the northwest. While Klein-Arendt (144-45) did not find any convincing etymology for this word, I think that it derives from onomatopoeia. It was perceived as such in Ngbandi, where it suggested the sound of big bellows. In Gbaya Yaayuwe, a related Ubangian language from Cameroon, vukutu-vukutu expresses the noise made by a big animal or a clothed person running or 
walking in the water. Moreover in many widely scattered cases, the sound and idea of "blowing" was rendered in non-Bantu languages and Bantu languages alike by such forms as -fuk or -fug (Efik and Turkana in KleinArendt, $145,{ }^{\circ}-p \hat{u}$ in various West African languages (Westermann 277), $-v u k$, or -ful, -vul (Ekoid in Crabb 56) or for Bantu: -fuka, -fula, -puta, $p u-p u-p u, f u p h u f u p h u$, -futha, etc. (Londo and Shona in Obenga 325; South Sotho) The semantic shifts involved from the original word are "to blow the bellows" > "bellows" > "the one who smelts" > "the smelting furnace." The reported Proto-reconstructions indicate a respectable antiquity for the word and suggest that it was perhaps first coined somewhere near or within the lake Tanganyika-Malawi corridor.

The distribution of ${ }^{\circ}-v u b a 3 / 4$ "bellows" is quite similar to ${ }^{\circ}-v u k u t a$ "to blow the bellows." But once again Guthrie, Ehret, and even KleinArendt (144) have erroneously assigned a set of reflexes from the northwest to the word they reconstructed as *-guba, so that for them the total distribution encompassed the whole area from west to east. This conflates two different words, namely, ${ }^{\circ}-k u ́ b a /$-gúba 5/6 "smithy" and "bellows" in the northwest, as opposed to ${ }^{\circ}-v n b a 3 / 4$ in the east. A summary of the reflexes of what we write as ${ }^{\circ}-v u b a$ actually consists of ${ }^{\circ}$-continual consonant-u- $\beta a$, in which $\beta$ is a fricative voiced labial. As Klein-Arendt (585-88) lists most reflexes I only need to add the following:

\section{-vuba 3/4 "bellows"-Map 6}

Lega

Lega-Sile

Komo

Rwanda

$\mathrm{Ha}$

Marachi

Hanga

Marama

Igembe

Kikuyu

ProtoSabaki

Sagala

Sandawe (Not Bantu)

Ngoni(Tanzania)

Tsonga $-g u b a 3 / 4$

-guba $3 / 4$

búba (de Mahieu, 252) but compare Bira, mbuba

"charcoal"

-vuba 3

$-v u b a 3 / 4$

-kuba 3/4 (Brown 173)

-kuba 3/4 (Brown 173)

-kuba 3/4 (Brown 173)

-vua 3/4 (Brown 173)

-ura 3

$-v u W a,-v u W o$ 3/4 (Nurse /Hinnebusch 622). ${ }^{22}$

-vuwa 4

muguba ((Ryohei Kagaya:39)

-vua (Brown 174)

$-v$ buvu 3

${ }^{22}$ Sabaki includes Swahili, Mwani, Elwana, Pokomo, Mijikenda, and Comorian. 
These reflexes constitute a single large and continuous distribution covering most of eastern, east central, and southeast Africa. Hence the word most likely spread from a single point of origin. It also was the last regional diffusion of any term designating bellows. In the absence of a convincing internal etymology in Bantu, Klein-Arendt (143-44) points to ${ }^{\circ}$-gub "to burn" in East and South Kushitic as the most likely origin of the Bantu word, although this does not explain the shape of the word in the Bantu languages closest to the Kushitic languages cited. But he did not consider the possibility that the word could have been coined from onomatopoeia, imitating the rush of air provoked by the bellows, a suggestion made by Rodegem (537) to explain the Rundi form. Actually the shape of most reflexes strongly supports this view and renders this a more likely origin for the word than a Kushitic one.

\section{$\mathbf{X}$}

Besides the words discussed here that relate to the initial introduction of iron-smelting or to a second stage of its diffusion, I briefly mention two later innovations. ${ }^{\circ}$-simbi "iron" (CS 339 Klein-Arendt 475-80) may well be the first word for "iron" to have spread in Bantu languages south of the Zambezi. It is ubiquitous there and many languages north of the Zambezi borrowed it from the south around or after 1900 with the meanings "steel" or "iron for ironing clothes." Without this recent diffusion, its northernmost reflexes are found in Tumbuka and Tonga-Malawi. (Guthrie 1:124 and topogram \# 25, 27; Ehret 128-29; Klein-Arendt 216$17,475-80$ ). The shape of the older distribution strongly suggests that the word spread from north to south during the first centuries CE, along with ironworking itself. In that case the word might have originated in Tumbu$\mathrm{ka}$ or Tonga-Malawi. But the word is also found in Lega-Sile -himbi /bimbe\# 3/4 "forged iron but not yet in its final shape" (Le Depluet) and may thus well have been coined in Maniema. True, Lamba and Ila both have -shimbi 6 "charcoal" (Doke 348; Smith/Dale 1:205-06), but a semantic shift "charcoal" > "iron" or vice versa sounds implausible. Other proposed etymologies such as a shift from Tswana ${ }^{\circ}$-sipa "to be stiff and sore as of a muscle" or from ${ }^{\circ}$-simbi "cowry" are even less plausible (Klein-Arendt 216; Ehret 128-29).

The second word, "-cuma "iron, iron object" has drawn the attention of all authors. It is derived by semantic shift from *-(j)ó\#ma 7 "item," "valuable thing" (CS 2162+ps. 542 and topogram \# 27: 1:140; Ehret 128; contra Klein-Arendt 219). Indeed the process of shifting is still ongoing in some languages, such as Nyiha, where -juma 7 "wealth, possession" is still the primary meaning, while the meaning "iron" refers specifically to "iron 
objects." Indeed the word recently lost its reference to iron goods altogether once cattle were in introduced into the area and replaced iron as the preferred store of wealth. ${ }^{23}$ The distribution of ${ }^{\circ}$-cuma consists in a single solid bloc of reflexes in the northeast of the Bantu-speaking area, including part of the Tanganyika/Malawi corridor and the Great Lakes, and its compact character suggests that it may not be very ancient, a point also made by Klein-Arendt (219). It might well have originated on the coast of Kenya and would then testify to an introduction of precious iron objects such as beads from overseas. But it might equally well have originated in or near the Great Lakes region, since it is also found in Lega Sile.

\section{XI}

According to their known distributions, the earliest words related to ironworking in Bantu languages were all introduced from non-Bantu languages spoken on the Nigerian plateau or in Adamawa. Even though these distributions are probably still incomplete for lack of data from many non-Bantu languages, they-and especially the distribution of ${ }^{\circ}-b o \# l o \#-$ fit quite well with an archeological record that documents a very early introduction of ironworking into northern and central Nigeria and in some adjacent sites in Cameroon and the Central African Republic. The phrase ntúla bo\#lo\# "to forge iron" used in Mbula just north of the upper Benue summarizes this well. It neatly captures both a more western distribution for ${ }^{\circ}$-túd- and a more eastern one for ${ }^{\circ}$-bo\#lo\# in a single phrase. From these places ironworking spread southwards along several pathways into Bantu-speaking lands, a spread that started long before $420 \mathrm{BCE}$. The evidence for this stems from the distribution of ${ }^{\circ}$-bo\#lo\# "bloom," o-tud"forging" and "-(j)o\#ndo "sledgehammer." These three words then strongly support the thesis that ironworking (smithing and probably ironsmelting as well) were introduced into the Bantu speaking subcontinent from Cameroon and Nigeria. In addition there is no evidence at all for any other introduction of the technology into the subcontinent from anywhere else.

Later when ironworking was spreading into Bantu -speaking regions, its practice generated two words with Bantu etymologies and a more southerly distribution than the older words. First ${ }^{\circ}$-kélwa "tuyère, drain for slag" between the Ubangi and the Congo rivers and later "-táde 14 "iron ore," most probably in Maniema and thus not far from the early archeological sites in the southern Great Lakes region, which are also dated to before $420 \mathrm{BCE}$. Yet the linguistic evidence suggests that the

${ }^{23}$ Busse 88 n1. 
Great Lakes region sites must be at least a century or two younger than the ones in Nigeria-Cameroon because ironworking first spread from there to the Great Lakes.

Still later a new set of innovations followed. This includes ${ }^{\circ}$-gela 7 "refined iron," o-vukuta "to activate the bellows," and ${ }^{\circ}-v u b a 3 / 4$ "bellows." Despite Klein-Arendt's attempts to seek an origin for the words in northeast Africa, the data are once again best explained as local innovations within Bantu, whether from *-ged "to flow" in the case of "-gela or from onomatopoeia in the case of the two other. Later again ${ }^{\circ}$-simbi 9/10 "iron ready for forging" spread with ironworking into southeast Africa, presumably between $c a$. $1 \mathrm{CE}$ and $500 \mathrm{CE}$ and finally $\mathrm{PB}{ }^{*}-(j) u m a$ 9/10 "valuable object" shifted its meaning to "iron" in parts of eastern Africa even more recently .

The linguistic evidence adduced here makes it clear that Africans did not invent ironworking independently anywhere in what is now Bantuspeaking Africa, but that the technology was obtained from West Africa. Similar linguistic studies there may perhaps help to resolve the issue whether West Africans invented the smelting of metals themselves or obtained the art from the shores of the Mediterranean. Meanwhile, one is struck by the rapidity with which this technology spread from Nigeria as far east as the Great Lakes, since it involved a mere four centuries at most, and this despite the technical complexity of iron-smelting. Why this was so and what made this speed possible are questions for future study.

Further linguistic research will certainly unearth evidence, especially from other hitherto poorly-reported non-Bantu languages, especially in Cameroon and Nigeria. But I do not expect that the main conclusions reached here will be overturned. More evidence will be very useful, however, to trace both the subsequent history of ironworking after its initial introduction in the various parts of the subcontinent. Both Klein-Arendt 's research (248-53) and my own uncovered regional clusters of sets. KleinArendt documents several of these in the eastern and southern savannas, but they are just as prominent in the central and western rainforests. For instance, the central rainforest region exhibits "-bo\#lo\# "bloom," o-peko "iron object," - $k u u k u$ "bellows," o-duta "to blow the bellows," -cákwá "smith's light hammer," as well as "-túd-and "-jondo. Future detailed studies of these regional sets, in conjunction with technological and stylistic studies, promise greatly to advance the long history of ironworking in various parts of Bantu-speaking Africa after its initial introduction .

Future research can also pay major dividends for students of historical linguistics because it can yield crucial chronological information (based on archeological data) about the emergence of various genetic subgroups 
within established language families such as in Bantu or Ubangian by establishing the presence of iron working vocabulary in the ancestral speech of such subgroups at various levels. For example, the data we have so far allow us to posit that ironworking was adopted in Proto-Gbaya times since it has "-bo\#lo\# "bloom," while there does not seem to be such an ancestral item in other Ubangian language groups such as the NgbakaSere-Ngbandi and Banda (Bouquiaux, Thomas). This means that the Gbaya group began to subdivide only after ca. $500 \mathrm{BCE}$ and that the Ngbaka-Sere-Ngbandi or Banda groups to its east adopted ironworking only after they had already begun to split into subgroups. In the same way detailed analysis of words relating to ironworking will eventually allow firmly to date the emergence of various genetic subsets of Bantu languages.

\section{Bibliography}

Alpern, Stanley B. "Did They or Didn't They Invent it?: Iron in Sub-Saharan Africa" History in Africa 31(2005), 41-94

Bahuchet Serge. Les pygmées Aka et la forêt centrafricaine. Paris, 1985.

Bastin Y. Bibliographie bantoue selective. Tervuren, 1975

Bennett, Patrick. "Bantu Technology and its Vocabulary" Muntu 3(1985), 121-36.

Blakney Charles P. "On Banana and Iron, Linguistic Footprints in African History." M.A. Thesis, Hartford, 1963.

BLR2. Coupez André, Yvonne Bastin, and Emile Mumba. Bantu Lexical reconstructions 2 . Computerized data base: http//www.linguistics.berkeley .Edu/COBOLD.

Bouquiaux, Luc, ed. L'expansion bantoue 3 vols. Paris 1980.

- and Jacqueline Thomas. "Le peuplement oubanguien." In L'expansion bantoue 3 vols. Paris 1980, 3:807-24.

Brown, Jean. Traditional Metalworking in Kenya. Oxford 1995.

Busse, Joseph. Die Sprache der Nyiha in Ost Afrika. Berlin, 1960.

Calloc'h, J. Vocabulaire Français-Gmbwaga-Gbanziri-Monjombo précédé d'élements de grammaire. Paris, 1911.

Cambier, Emile. Essais sur la langue congolaise. Bruxelles, 1891.

Charreau, M.P. "Un coin du Congo. Le cercle de Kundé." Bulletin de la Société Nationale des Sciences Naturelles et Mathématiques de Cherbourg 35(1905/06), 1-212.

Copet, Elizabeth. personal communication (Mpiemu wordlist).

Courboin Albert. Bangala, langue commerciale du Haut-Congo. Antwerp, 1908. 
Crabb, David W. Ekoid Bantu Languages of Ogoja. Cambridge, 1965.

Czekanowski, Jan. Forschungen im Nil-Congo Zwischengebiet 6 vols. Leipzig, 1911-27.

Delhaise, Arnould. "Chez les Wasongola du Sud Bantu ou Ba-Bili" Bulletin de la Société Royale Belge de Géographie 33(1909), 34-58, 109-35, 159-214.

Doke, Clement M. The Lambas of Northern Rhodesia. London, 1931.

Dupré, Georges. Un ordre et sa destruction. Paris, 1982.

Ehret, Christopher. "The Establishment of Iron-Working in Eastern, Central, and Southern Africa: Linguistic Inferences on Technological History" Sprache und Geschichte in Afrika 16/17(2000), 125-76.

Forges, Germaine. Le Kela, langue bantoue du Zaïre (zône C). Esquisse phonologique et morphologique. Paris, 1977.

Gaud, Fernand. Les Mandja (Congo Français). Bruxelles, 1911.

Gerhardt, Ludwig. "Analytische und vergleichende Untersuchungen zu einigen zentralnigerianischen Klassensprachen" Afrika und Üebersee 51(1967) 161-98; 52(1968), 23-57, 125-43, 207-42.

-. "Bali (Mungaka), Proto-Grassfield und Proto-Bantu" Afrika und Übersee 81(1998), 1-19.

-. "Jarawan Bantu: the Mistaken Identity of the Bantu Who turned North" Afrika und Übersee 65(1982), 75-95

Guarisma, Gladys. Etudes Voute (langue bantoïde du Cameroun). Paris, 1978.

Guthrie, Malcolm, Comparative Bantu 4 vols. Farnborough 1967-71.

Guttmann, Bruno. "Der Schmied und seine Kunst in animistischer Denken" Zeitschrift für Ethnologie 44(1912), 81-93.

Hagege, Claude. Description phonologique du mbum. 2d ed. Paris, 1968.

Heine, Berndt and Derek Nurse. eds. African Languages. Cambridge, 2000.

Hendrix, Melvin K. An International Bibliography of African Lexicons. Metuchen, 1982:

Hino, Shun'ya. The Classified Vocabulary of the Mbum Language in Mbang Mboum, with Ethnographical Description. Tokyo 1978.

Holl, Augustine. "Cameroun," in Lanfranchi/Clist, 192-96.

Jézégou, M. P. and Bernard Clist. "Congo," in Lanfranchi/Clist, 202-07.

Johnston, Harry H. A Comparative Study of the Bantu and Semi-Bantu Languages 2 vols. Oxford 1919.

-. The Uganda Protectorate 2 vols. London, 1904.

Kagaya, Ryohei. A Classified Vocabulary of the Sandawe Language. Tokyo, 1993.

Kanimba, Misago. "Zaïe" in Lanfranchi/Clist, 211-17.

Killick, David. "What Do We Know About African Iron Working?" Journal of African Archaeology 2(2004), 97-112.

Kita Kyankenge Masandi. "La technique traditionnelle de la métallurgie du fer chez les Balega de Pangi (Zaïre)." Muntu 3(1985), 85-99. 
Klein, Hildegard. ed. Leo Frobenius. Ethnographische Notizen aus den Jahren 1905 und 19064 vols. Wiesbaden 1985-90.

Klein-Arendt, Reinhard. Die traditionellen Eisenhandwerke der SavannaBantu: Eine sprachbistorische Rekonstruktion auf lexicalischer Grundlage. Frankfurt 2004.

Koelle, Sigismund Wilhelm. Polyglotta Africana. London 1854.

Labroussi, Cathérine, "Vowel Systems and Spirantization in S.W.Tanzania." In Jean-Marie Hombert and Larry M. Hyman, eds. Bantu Historical Linguistics: Theoretical and Empirical Perspectives. Stanford, 1999, 33577.

Lamal, F. Basuku et Bayaka des districts Kwango et Kwilu du Congo. Tervuren, 1965.

Laman, Karl. Kikongo-Français. Brussels, 1936.

Lanfranchi, Raymond and Bernard Clist. eds. Aux origines de l'Afrique centrale. Paris. 1991.

Le Depluet. "Résumé de la grammaire Kisile." Manuscript n.d. (post-1945). Museum for Central Africa. Tervuren: Linguistic Section.

Leitch, Miles. "Babole (C101)." in Nurse Derek, and Gérard Phillipson. The Bantu Languages. London, 2003.

Lekens, Benjamin. Dictionnaire Ngbandi. Tervuren, 1952.

Lukas, Johannes. Zentralsudanische Studien. Hamburg 1937.

- and Ludwig Gerhardt. "Bemerkungen zur Sprache der Mbula." in Festschrift zum 60. Geburtstag von P. Anton Vorbichler. 2 vols. Vienna, 1981, 1:71-90.

- and Alfred Willms. "Outline of the Language of the Jarawa in Northern Nigeria." Afrika und Übersee 45(1961), 1-66; 46(1962), 47-66.

MacEachern, Scott. "Western African Iron Age." in Vogel Joseph, ed. Encyclopedia of Precolonial Africa. Walnut Creek, CA, 1997, 425-29.

Maddieson, Ian and Kay Williamson. "Jarawan Bantu" African Languages 1(1975), 125-63.

Maes, V. Dictionnaire Ngbaka-Français-Néerlandais. Tervuren, 1959.

Mahieu, Wauthier de. "Les structures sociales du groupe komo dans leur elaboration symbolique" (PhD, Katolieke Universiteit te Leuven, 1975).

Mann Michael and David Dalby. A Thesaurus of African Languages. London, 1987.

Mansfeld, Alfred. Urwald-Dokumente. Berlin, 1908.

Maquet, Emma. Outils de forge du Congo, du Rwanda et du Burundi. Tervuren, 1965.

Maret, Pierre de and F. Nsuka. "History of Bantu Metallurgy: Some Linguistic Aspects" History in Africa 4(1977), 43-65.

McMaster Mary. "Patterns of Interaction: a Comparative Ethnolinguistic Perspective on the Uele Region of Zaire c. 500 B.C. to A.D. 1900" (PhD., UCLA, 1988). 
Meek, Charles K. Tribal Studies in Northern Nigeria 2 vols. London, 1931.

-. A Sudanese Kingdom: an Ethnographical Study of the Jukun-speaking Peoples of Nigeria. London, 1931.

Meeussen, A. Emiel. Bantu Lexical Reconstructions. Tervuren, 1980.

Meier, Wilma. Bibliography of African Languages. Wiesbaden, 1984.

Meyer, Emmi. "Material zur Yogo-Sprache." Zeitschrift für EingeborenenSprachen 33(1942/43), 1-24.

Moñino, Yves. Lexique comparatif des langues oubanguiennes. Paris, 1988.

Mopila F.J. Memorias de un Congoles. Madrid, 1949.

Mouchet, Jean. "Vocabulaire comparatif de quinze parlers du nordCameroun." Etudes Camerounaises 29/30(1952), 5-74.

- Le parler Daba. Yaoundé, 1966.

Nogueira, António Ferreira. "O lu'nkunbi." Boletim da Sociedade de Geographia de Lisboa 5/4(1885), 181-255.

Noss, Philip. Lexique Français-Gbaya. Dialectes Yaáyuwee-Dooka-Lai-Mbódomo. Manuscript.

-. Personal communication (Mkako, Bera, Gbaya wordlist). n.d.

Nsuka-Nkutsi, François and Pierre de Maret. "Etude comparative de quelques termes métallurgiques dans les langues bantoues" in Bouquiaux, Expansion bantoue, 3:371-442.

Nurse, Derek. "The Diachronic Background to the Language Communities in Southwestern Tanzania." Sprache und Geschichte in Afrika 9(1988), 15115.

- and Thomas J. Hinnebusch. Swahili and Sabaki: a Linguistic History. Berkeley, 1993.

- and Gérard Phillipson. The Bantu Languages. London, 2003.

Obenga, Théophile. Les Bantu, langues, peoples, civilization. Paris, 1985.

-. La cuvette congolaise: les hommes et les structures. Paris, 1976.

Ouzilleau, F. "Note sur la langue des pygmées de la Sangha suivie de vocabulaires." Revue d'ethnographie et de sociologie 2(1911), 75-92.

Périquet, L. Rapport général sur la mission de délimitation Afrique Equatoriale Française-Cameroun (1912-1913-1914). Paris, 1915.

Piron, Pascale. "Classification interne du groupe bantoide" (PhD, Université Libre de Bruxelles, 1996).

Plancquaert, Marcel. Les Yaka: essai d'histoire. Tervuren, 1971.

Pontié, Guy. Les Guiziga du Cameroun septentrional. Paris, 1973.

Pweddon, Nicholas Nzovudeto and A. Neil Skinner. Bwatiye-English Dictionary with English-Bwatye Index. Madison, 2001.

Renouf-Stefanik, Suzanne. Animisme et Islam chez les Manza (Centrafrique) 2 vols. Paris 1978.

Reynolds, Barry. The Material Culture of the Peoples of the Gwembe Valley. New York, 1968. 
Robertson, John. "Early Iron Age Archaeology in Central Zambia" Azania 35(2000), 147-81.

Rodegem, F.M. Dictionnaire rundi-français. Tervuren, 1970.

Samarin, William J. The Gbeya Language: Grammar, Texts, and Vocabularies. Berkeley, 1966.

Schoenbrun, David. The Historical Reconstruction of Great Lakes Bantu

Cultural Vocabulary: Etymologies and Distributions. Cologne, 1997.

Schürle, Georg. Die Sprache der Basa in Kamerun. Hamburg, 1912.

Shimizu, Kiyoshi. Comparative Jukunoid. Vienna, 1980.

Smith, Edwin W. and Andrew M. Dale. The Ila-Speaking Peoples of Northern Rhodesia 2 d ed. 2 vols. New York, 1968.

Stirnimann, Hans. Existenzgrundlagen und traditionelles Handwerk der Pangwa von SW.-Tansania. Fribourg, 1976.

Stöckler, J. Mungaka (Bali) Dictionary rev. and trans. Cologne, 1992.

Storch, Anne. Das Hone und seine Stellung in Zentral Jukunoid. Cologne, 1999.

Struck, Bernhard. "Vokabularien der Bakondjo-, Baamba-, Bambuba-, Babira, Balega-, Lendu- und Banyarisprachen." Mitteilungen des Seminars für Orientalischen Sprachen 13(1910), 133-65.

Stern, R. "Die Gewinnung des Eisen bei den Nyamwezi." Appendix to Franz Stuhlmann, Handwerk und Industrie in Ostafrika. Hamburg, 1910, 15263.

Talbot, P. Amaury. In the Shadow of the Bush. London, 1912.

Tessmann, Günther. "Die Sprachen der Mbaka-Limba, Mbum und Lakka. Wörterlisten und Grammatik." Mitteilungen des Seminar für Orientalische Sprachen 33/3(1930), 55-82.

-. Die Bafia. Stuttgart, 1934.

Thomas, Northcote W. Specimens of Languages from Southern Nigeria 2 vols. London, 1913.

Torday, Emil. Notes ethnographiques sur les populations habitant les basins du Kasaï et du Kwango oriental. Brussels, 1922.

Torrend, J. An English-Vernacular Dictionary of the Bantu-Botatwe Dialects of Northern Rhodesia. Mariannhill, 1931.

Tucker Archibald N. and P.E. Hackett. Le groupe linguistique zande. Tervuren, 1959.

Van Geluwe, Huguette. Mamvu-Mangutu et Balese-Mvuba. Tervuren, 1957.

Van Leynseele, Helene and John Stewart. "Harmonie consonantique en prénen." in Luc Bouquiaux. ed., L'expansion bantoue 2 vols. Paris 1980, 2:421-33.

Van Noten, Francis. "Het Ijzersmelten bij de Madi." Africa-Tervuren 20(1974), 57-66.

Vergiat A.M. Moeurs et coutumes des Manjas. Paris, 1937. 
Vogel, Joseph. ed.. Encyclopedia of Precolonial Africa. Walnut Creek CA, 1997.

Volavka, Zdenka. Crown and Ritual: The Royal Insignia of Ngoyo. Toronto. 1998.

Wambat, François. "Esquisse d'histoire économique et sociale des Yamunzombo de l'Oubangui: Centrafrique, Congo-Zaïre (de la fin du XVIIIès à la fin du XXès" (thèse de doctorat, Université de Paris I, 1985).

Wente-Lukas, Renate. Die materielle Kultur der nicht-islamischen Ethnien von Nordkamerun und Nordostnigeria. Wiesbaden, 1977.

Westermann, Dietrich. Die westlichen Sudansprachen und Ibre Beziehungen zum Bantu. Berlin, 1927. 